In cooperation with the U.S. Army Corps of Engineers, Fort Worth District; San Antonio River Authority; San Antonio Water System; and Guadalupe-Blanco River Authority

\title{
Simulation of Streamflow and Estimation of Ground-Water Recharge in the Upper Cibolo Creek Watershed, South-Central Texas, 1992-2004
}

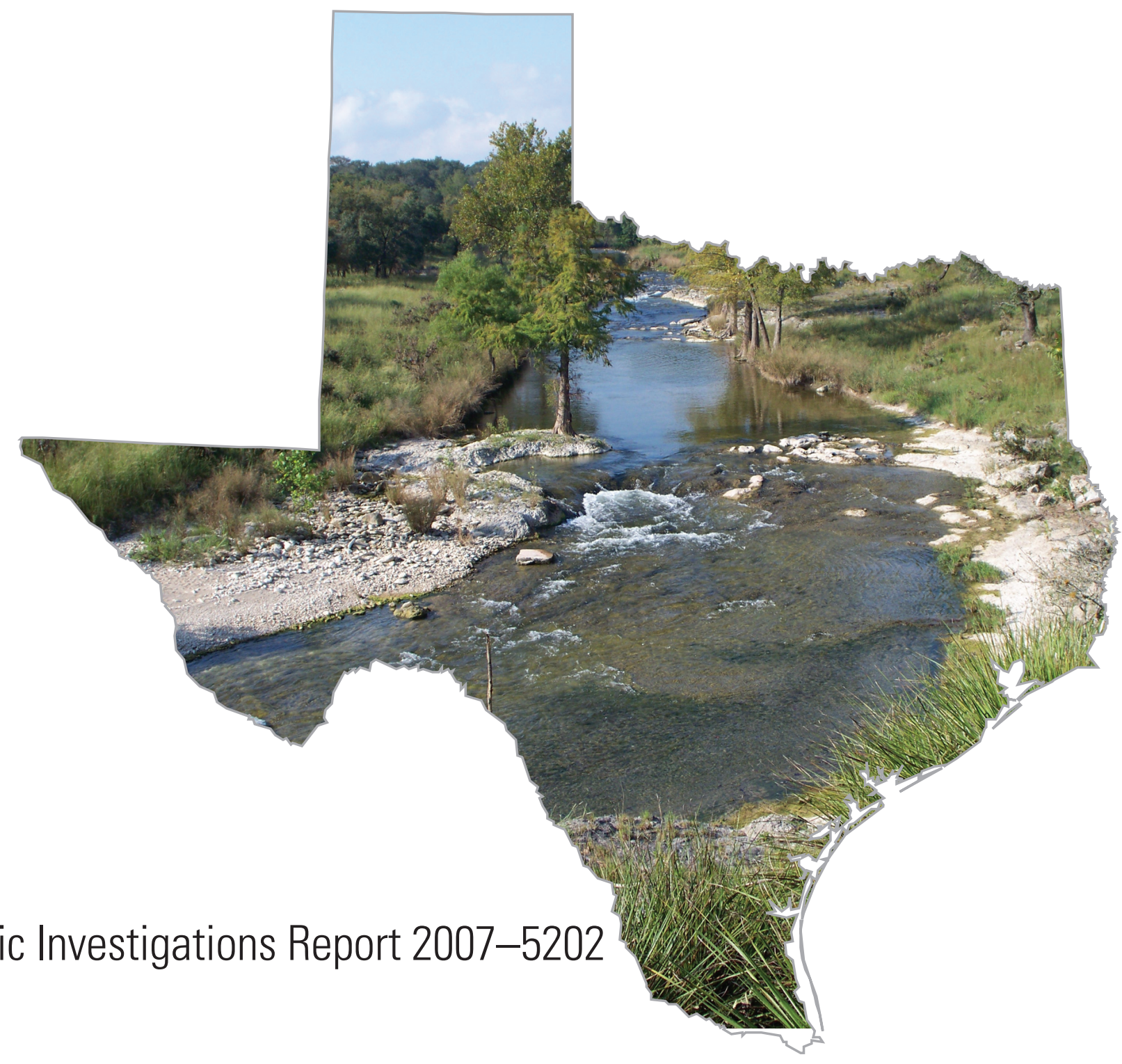


Cover: Cibolo Creek downstream from Boerne, Tex., September 21, 2007. 


\section{Simulation of Streamflow and Estimation of Ground-Water Recharge in the Upper Cibolo Creek Watershed, South-Central Texas, 1992-2004}

By Darwin J. Ockerman

In cooperation with the U.S. Army Corps of Engineers, Fort Worth District; San Antonio River Authority; San Antonio Water System; and GuadalupeBlanco River Authority

Scientific Investigations Report 2007-5202 


\section{U.S. Department of the Interior DIRK KEMPTHORNE, Secretary}

\section{U.S. Geological Survey \\ Mark D. Myers, Director}

\section{U.S. Geological Survey, Reston, Virginia: 2007}

For product and ordering information:

World Wide Web: http://www.usgs.gov/pubprod

Telephone: 1-888-ASK-USGS

For more information on the USGS — the Federal source for science about the Earth, its natural and living resources, natural hazards, and the environment:

World Wide Web: http://www.usgs.gov

Telephone: 1-888-ASK-USGS

Any use of trade, product, or firm names is for descriptive purposes only and does not imply endorsement by the U.S. Government.

Although this report is in the public domain, permission must be secured from the individual copyright owners to reproduce any copyrighted materials contained within this report.

Suggested citation:

Ockerman, D.J., 2007, Simulation of streamflow and estimation of ground-water recharge in the upper Cibolo Creek watershed, south-central Texas, 1992-2004: U.S. Geological Survey Scientific Investigations Report 2007-5202, $34 \mathrm{p}$. 


\section{Contents}

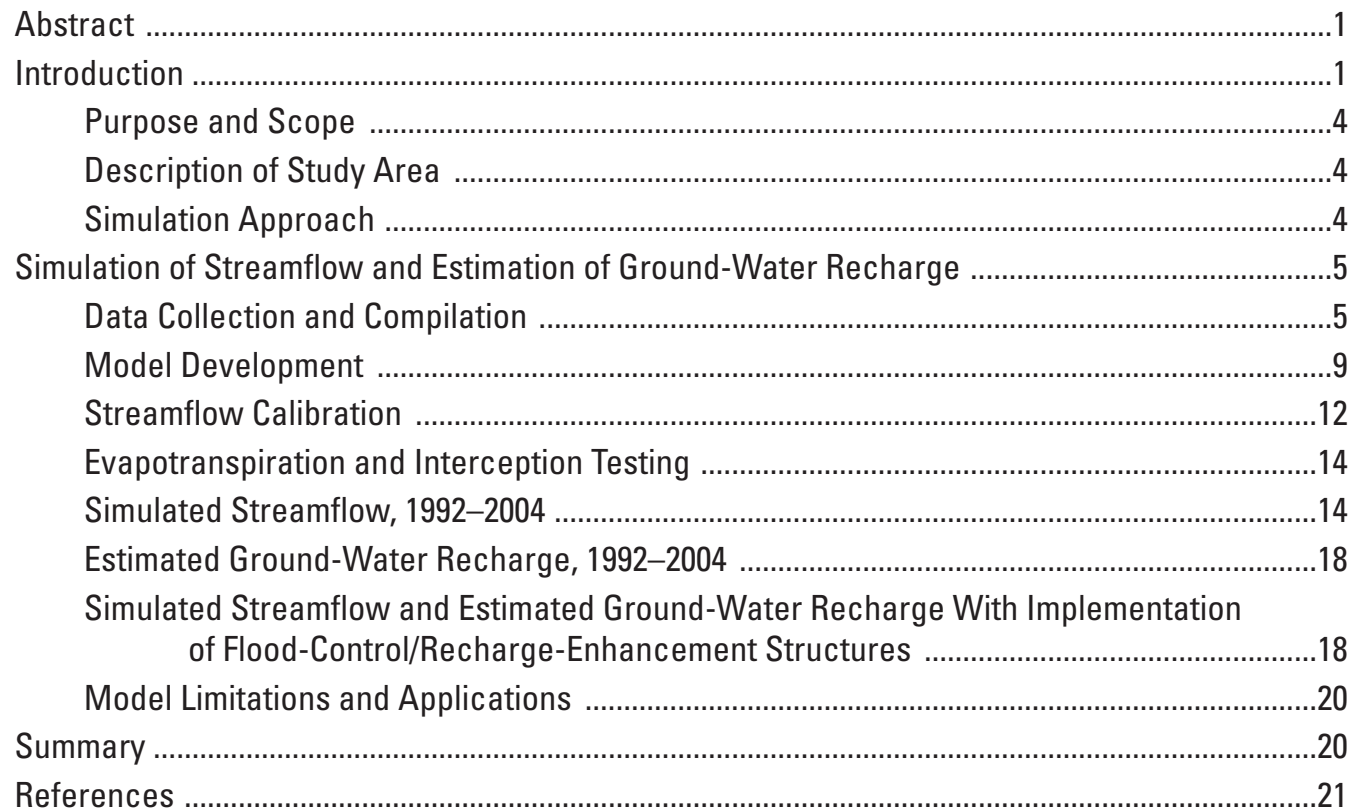

\section{Figures}

1-2. Maps showing:

1. Location of Cibolo Creek watershed and study area, south-central Texas .............2

2. Location of Trinity aquifer outcrop, Edwards aquifer recharge zone (outcrop), and Edwards aquifer upper confining unit, upper Cibolo Creek watershed, south-central Texas

3. Diagram showing hydrological Simulation Program-FORTRAN (HSPF) flowchart for (a) impervious and (b) pervious land segments

4-6. Maps showing:

4. Land cover in the upper Cibolo Creek watershed, south-central Texas

5. Data-collection stations that provided data for Hydrological Simulation Program-FORTRAN model, upper Cibolo Creek watershed, south-central Texas

6. Stream-reach network for the Hydrological Simulation Program—FORTRAN model, upper Cibolo Creek watershed, south-central Texas

7-9. Graphs showing

7. Measured and simulated daily streamflow at station 08183850 Cibolo Creek at Interstate Highway 10 above Boerne, Texas, 1997-2004

8. Measured and simulated daily streamflow at station 08183900 Cibolo Creek near Boerne, Texas, 1992-94

9. Measured and simulated daily streamflow at station 08185000 Cibolo Creek near Selma, Texas, 1997-2004

10. Map showing locations of flood-control/recharge-enhancement structures and impoundment areas simulated with the Hydrological Simulation ProgramFORTRAN model, upper Cibolo Creek watershed, south-central Texas 


\section{Tables}

1. Process-related model parameters for the Hydrologic Simulation ProgramFORTRAN model

2. Basin-related model parameters for the Hydrologic Simulation ProgramFORTRAN model

3. Land-cover categories and areas for the upper Cibolo Creek watershed, southcentral Texas

4. Data-collection stations that provided data for the Hydrologic Simulation Program-FORTRAN model, upper Cibolo Creek watershed, south-central Texas ......11

5. Streamflow calibration and testing results, Hydrological Simulation ProgramFORTRAN model, upper Cibolo Creek watershed, south-central Texas, 1992-2004 ......23

6. Simulated evapotranspiration, upper Cibolo Creek watershed, and measured evapotranspiration, Honey Creek watershed, south-central Texas, MarchDecember 2002

7. Selected annual PERLND and IMPLND process-related parameters for the Hydrological Simulation Program-FORTRAN model, upper Cibolo Creek watershed, south-central Texas

8. Monthly values of lower-zone evapotranspiration (LZETP) parameter for the Hydrological Simulation Program-FORTRAN model, upper Cibolo Creek watershed, south-central Texas

9. Measured and simulated average annual streamflow per unit area (runoff) at selected sites on Cibolo Creek, south-central Texas, 1992-2004

10. Estimated annual rainfall and ground-water recharge, upper Cibolo Creek watershed, south-central Texas, 1992-2004

11. Estimated average annual rainfall, diffuse recharge, stream-channel recharge, and total recharge by surficial unit, upper Cibolo Creek watershed, south-central Texas

12. Specifications of flood-control/recharge-enhancement structures simulated with the Hydrological Simulation Program-FORTRAN model, upper Cibolo Creek watershed, south-central Texas

13. Simulation results for various scenarios of flood-control/recharge-enhancement structure implementation using the Hydrological Simulation Program-FORTRAN model, upper Cibolo Creek watershed, south-central Texas.

\section{Datum}

Horizontal coordinate information is referenced to the North American Datum of 1983 (NAD 83). 


\title{
Simulation of Streamflow and Estimation of Ground-Water Recharge in the Upper Cibolo Creek Watershed, South-Central Texas, 1992-2004
}

\author{
By Darwin J. Ockerman
}

\section{Abstract}

A watershed model (Hydrological Simulation ProgramFORTRAN) was developed, calibrated, and tested by the U.S. Geological Survey, in cooperation with the U.S. Army Corps of Engineers, San Antonio River Authority, San Antonio Water System, and Guadalupe-Blanco River Authority, to simulate streamflow and estimate ground-water recharge in the upper Cibolo Creek watershed in south-central Texas. Rainfall, evapotranspiration, and streamflow data were collected during 1992-2004 for model calibrations and simulations. Estimates of average ground-water recharge during 1992-2004 from simulation were 79,800 acre-feet (5.47 inches) per year or about 15 percent of rainfall. Most of the recharge (about 74 percent) occurred as infiltration of streamflow in Cibolo Creek. The remaining recharge occurred as diffuse infiltration of rainfall through the soil and rock layers and karst features. Most recharge (about 77 percent) occurred in the Trinity aquifer outcrop. The remaining 23 percent occurred in the downstream part of the watershed that includes the Edwards aquifer recharge zone (outcrop). Streamflow and recharge in the study area are greatly influenced by large storms. Storms during June 1997, October 1998, and July 2002 accounted for about 11 percent of study-area rainfall, 61 percent of streamflow, and 16 percent of the total ground-water recharge during 1992-2004. Annual streamflow and recharge also were highly variable. During 1999, a dry year with about 16 inches of rain and no measurable runoff at the watershed outlet, recharge in the watershed amounted to only 0.99 inch compared with 13.43 inches during 1992, a relatively wet year with about 54 inches of rainfall. Simulation of flood-control/rechargeenhancement structures showed that certain structures might reduce flood peaks and increase recharge. Simulation of individual structures on tributaries showed relatively little effect. Larger structures on the main stem of Cibolo Creek were more effective than structures on tributaries, both in terms of floodpeak reduction and recharge enhancement. One simulated scenario that incorporated two main-stem structures resulted in a 37-percent reduction of peak flow at the watershed outlet and increases in stream-channel recharge of 6.6 percent in the Trinity aquifer outcrop and 12.6 percent in the Edwards aquifer (recharge zone) outcrop.

\section{Introduction}

The U.S. Army Corps of Engineers (USACE), Fort Worth District, began a study in 2002 to address opportunities for ecosystem restoration (in part, through aquifer recharge), flood-damage reduction, and watershed management through Best Management Practices (BMP) in the upper Cibolo Creek watershed (study area) in south-central Texas (fig. 1). Phase 1 of the study (the first of three phases) consists of establishing and documenting the existing hydrologic, engineering, economic, and environmental conditions for the study area (U.S. Army Corps of Engineers, 2001). As part of phase 1, the U.S. Geological Survey (USGS), in cooperation with the USACE, San Antonio River Authority (SARA), San Antonio Water System (SAWS), and Guadalupe-Blanco River Authority (GBRA), developed, calibrated, and tested a watershed model of the study area using the Hydrological Simulation Program-FORTRAN (HSPF) to simulate existing hydrologic conditions. Phase 2 of the study involves evaluation of possible alternatives to address ecosystem restoration, flooddamage reduction, and watershed management opportunities. As part of phase 2, the USGS used the HSPF model developed in phase 1 to evaluate the effects of flood-control/rechargeenhancement structures on streamflow and aquifer recharge in the watershed. Phase 3 of the study is a detailed engineering analysis by the project cooperators of possible alternatives evaluated in phase 2 .

Part of the study area is in the Edwards aquifer recharge zone (outcrop) (fig. 2). The Edwards aquifer is one of the most productive carbonate aquifers in the Nation and is the major source of public water supply in south-central Texas. In addition, the Edwards aquifer supplies large quantities 


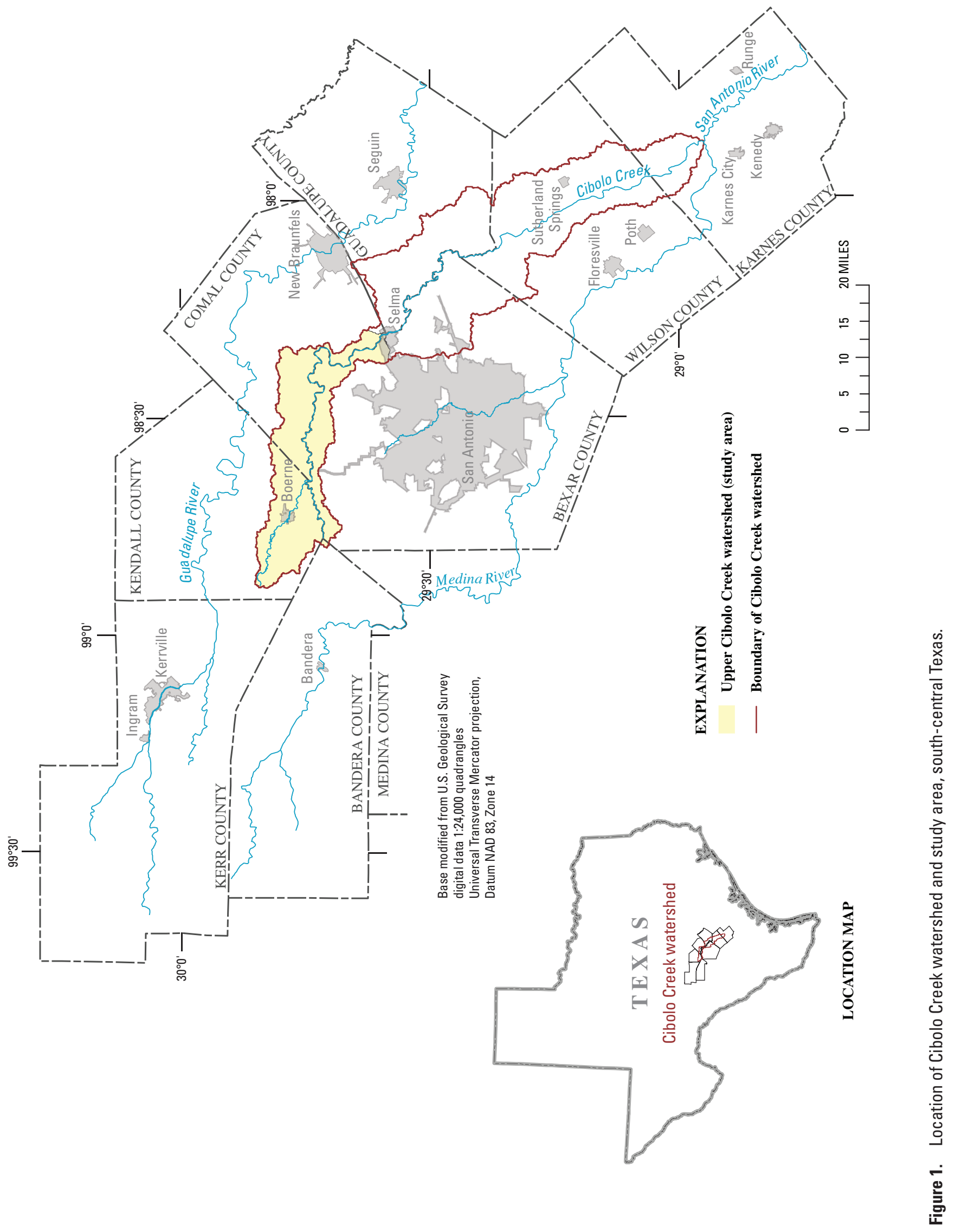




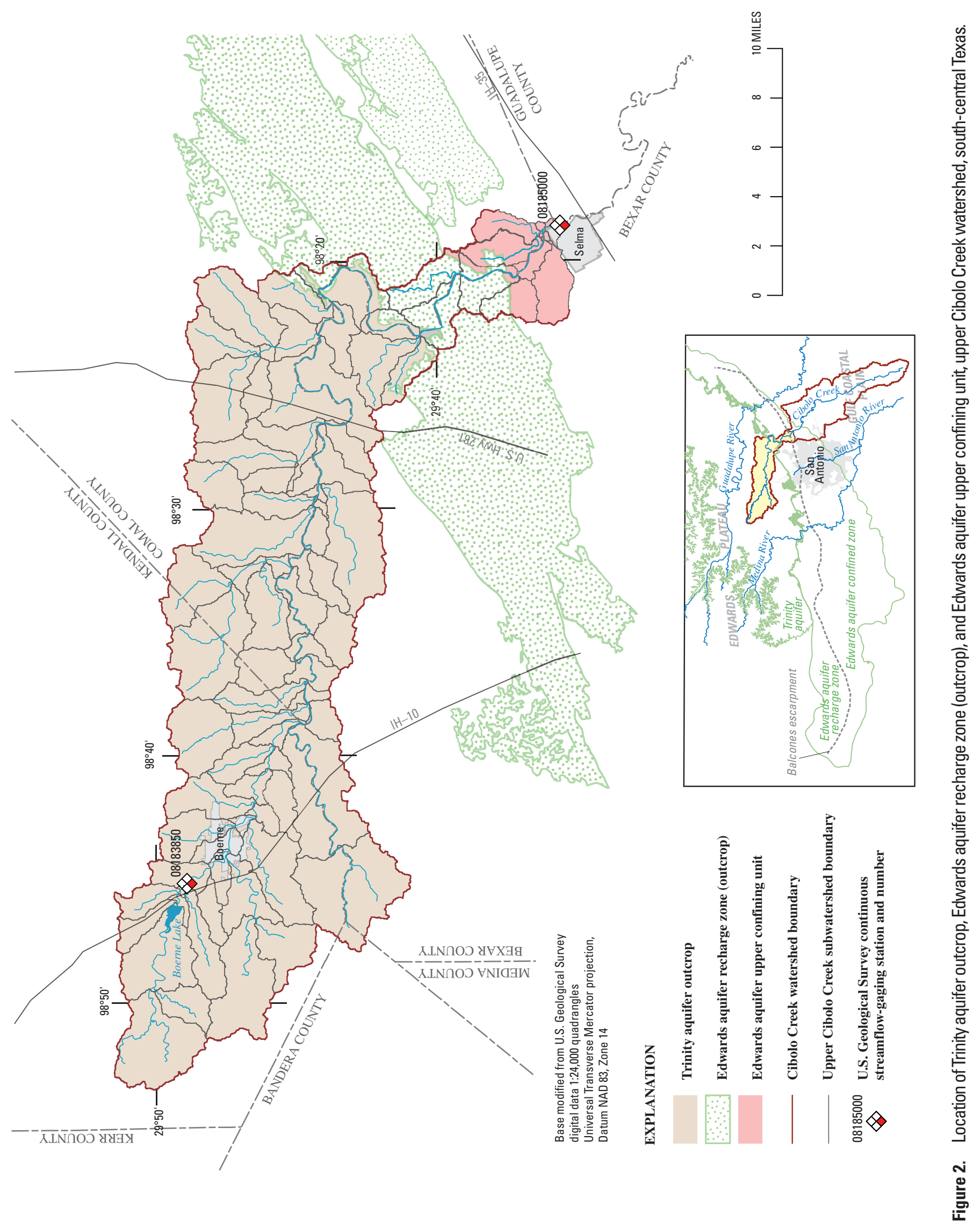


of water for agriculture, industry, military installations, and recreational activities. The aquifer also is a source of water to major springs in the region. These springs supply water to downstream users and provide habitat for several threatened or endangered species.

The Trinity aquifer, adjacent to the Edwards aquifer to the north (fig. 2), also is an important ground-water resource in the study area. The Trinity aquifer outcrop (primarily Glen Rose Limestone) encompasses most of the study area, and many residents in the study area rely on Trinity aquifer wells for water supply.

\section{Purpose and Scope}

The purpose of this report is to describe the development, calibration, testing, and use of the HSPF model to simulate streamflow and estimate ground-water recharge in the upper Cibolo Creek watershed. Calibration and testing of the model was based on data collected during 1992-2004. Streamflow and ground-water recharge estimates also are provided for 1992-2004. The calibrated HSPF model also was used to simulate streamflow and recharge conditions for scenarios that included flood-control/recharge-enhancement structures. Results of these simulations are included in the report. This report documents the work of the USGS as a part of phases 1 and 2 of the USACE study.

\section{Description of Study Area}

The study area (upper Cibolo Creek watershed) is north of San Antonio and includes parts of Bandera, Bexar, Comal, and Kendall Counties (fig. 1). The town of Boerne, in the northwestern part of the study area (fig. 2), is the largest population center with about 6,100 residents (City of Boerne, 2003).

Cibolo Creek begins about 10 miles northwest of Boerne in southwestern Kendall County and flows southeastward for about 100 miles, forming the Bexar-Comal County and BexarGuadalupe County boundaries and crossing Wilson County, to its mouth on the San Antonio River in Karnes County (fig. 1). The entire drainage area of Cibolo Creek is 856 square miles. This study focuses on upper Cibolo Creek and its 274-squaremile drainage area upstream from USGS streamflow-gaging station 08185000 Cibolo Creek at Selma (fig. 2).

The study area is described as having a subtropical, subhumid climate characterized by hot summers and mild, dry winters (Larkin and Bomar, 1983). Heaviest rainfall tends to occur in spring, early summer, and fall. Average annual rainfall (1961-90) in the study area is about 34 inches per year (Bomar, 1994). During the study period (1992-2004), average annual rainfall in the upper Cibolo Creek watershed was 37.43 inches. The (San Antonio) average monthly low temperature ranges from 37.9 degrees Fahrenheit $\left({ }^{\circ} \mathrm{F}\right)$ in January to $75.0^{\circ} \mathrm{F}$ in July. Average monthly high temperature ranges from 60.8 ${ }^{\circ} \mathrm{F}$ in January to $95.3^{\circ} \mathrm{F}$ in August (Bomar, 1994).
The study area includes parts of the southern margin of the Edwards Plateau (often referred to as the Texas Hill Country), the northern limit of the Gulf Coastal Plain, and the Balcones escarpment (a prominent topological feature of variable relief that separates the Edwards Plateau from the Gulf Coastal Plain) (fig. 2). Altitude in the study area ranges from about 728 to 2,000 feet above sea level. Land slopes generally are steeper in the upstream part of the study area than in the downstream part.

The study area includes outcrops of the Edwards and Trinity aquifers. Both aquifer outcrops are characterized by thin, rocky soils, and moderate to steep slopes. Compared to rocks of the Edwards Group and Georgetown Formation (Edwards aquifer), rocks of the Glen Rose Limestone (Trinity aquifer) generally have low porosity and little permeability (Clark, 2003). However, stream channels crossing both aquifer outcrops lose flow through infiltration into faults, sinkholes, and other karst features (Texas Board of Water Engineers, 1960). Because of high infiltration rates to ground water in the stream channels, streamflow is relatively infrequent, especially toward the downstream end of the study area. More than 95 percent of the time, streamflow is zero at the USGS gaging station Cibolo Creek at Selma (operated since 1946), flowing only during or after relatively heavy rainfall. Streamflow losses on the Edwards aquifer outcrop are believed to contribute directly to Edwards aquifer recharge (Puente, 1978). Streamflow losses to the Trinity aquifer outcrop also might contribute to Edwards aquifer recharge. It is believed that some of the Cibolo Creek streamflow infiltration to the Trinity aquifer passes laterally through underground channels into the Edwards aquifer (George, 1952).

Land cover in the study area is mostly undeveloped rangeland, consisting of open to dense stands of juniper, oak, and shrub (University of Texas, Bureau of Economic Geology, 1995). Cultivated land generally is scarce because of poor or thin soils. Development (primarily residential) in the study area is increasing at a relatively rapid rate. During 1990-2000, the populations of Comal and Kendall Counties increased by 50.5 and 62.7 percent, respectively, compared with an increase of 22.8 percent for the State of Texas during the same period (U.S. Census Bureau, 2003).

Boerne Lake, upstream from Boerne (fig. 2) and completed in 1978, supplies drinking water for Boerne and is the only reservoir in the study area. The Boerne municipal wastewater treatment facility discharges about 600,000 gallons per day to Cibolo Creek downstream from Boerne (Michael Veazy, Texas Commission on Environmental Quality, written commun., 2001). Flow from this continual discharge usually does not travel very far downstream, but infiltrates within the Cibolo Creek stream channel to the underlying aquifers.

\section{Simulation Approach}

Because of the complex combination of watershed characteristics and hydrologic processes affecting streamflow and 
recharge in the study area, a comprehensive watershed model was needed to account for the dynamic water-balance conditions and to simulate streamflow and ground-water recharge. Also, a watershed model was necessary to estimate changes in streamflow and recharge that might occur because of future changes in watershed characteristics (for example, land-use changes and implementation of flood-control projects). The HSPF model was selected for modeling the study area because it is one of the most comprehensive watershed models available, can simulate a wide variety of stream and watershed conditions with reasonable accuracy, and enables flexibility in adjusting the model to simulate alternative conditions, or scenarios (Donigian and others, 1995).

HSPF is a watershed model used to simulate hydrologic processes in complex agricultural, rural, and urban watersheds. HSPF uses information such as the time history of rainfall, temperature, evaporation, and parameters related to land cover, land-use practices, and soil characteristics to simulate hydrologic processes that occur in a watershed. The result of an HSPF simulation is a time history of the quantity of water transported over the land surface and downward through the various soil zones to the aquifers (Donigian and others, 1995).

In HSPF, a watershed is represented by a group of hydrologically similar areas that are referred to as hydrologic response units (HRUs) that drain to a network of reaches (RCHRESs) consisting of stream segments, lakes, or reservoirs. Each RCHRES is contained in and corresponds to a subwatershed. HRUs reflect areas of similar land use, surficial geology, and other factors deemed important to produce a similar hydrologic response to precipitation and potential (pan) evaporation. HRUs are divided into segments of pervious land (PERLND) and impervious land (IMPLND). Pervious land is represented conceptually within HSPF by a series of interconnected water-storage zones: an upper zone, a lower zone, and a ground-water zone. Impervious land is represented by simpler surface storage, evaporation, and runoff processes. Hydraulic functioning of stream reaches (open or closed channels, or completely mixed lakes) is simulated using storage routing (Donigian and others, 1995).

The HSPF model simulates water movement through and across impervious and pervious land to the atmosphere, ground water, or surface runoff (fig. 3). The flow of water between the storage zones, stream, and atmosphere is affected by the process-related model parameters listed in table 1 .

The process-related model parameters for each land segment are adjusted to calibrate the model. The following process-related parameters can be automatically adjusted, by month, to account for seasonal variations: interception storage capacity (CEPSC), interflow index (INTFW), interflow recession coefficient (IRC), lower-zone evapotranspiration (LZETP), Manning's n for assumed overland flow plane (NSUR), and upper-zone nominal storage (UZSN). For this study, monthly variation was implemented only for parameters CEPSC and LZETP. The HSPF user's manual (Bicknell and others, 1997) provides a more complete description of each parameter.
The six basin-related model parameters listed in table 2 define the areal extent of each land segment and characteristics of each stream or reservoir segment, including length and tables of surface area, volume, and streamflow (discharge), as a function of depth. These parameters represent the physical characteristics of each land or stream segment in a watershed and generally remain unchanged during calibration of the model.

\section{Simulation of Streamflow and Estimation of Ground-Water Recharge}

The major steps for simulating streamflow and estimating ground-water recharge for the study area included (1) data collection and compilation; (2) model development, calibration, and testing; and (3) simulation of streamflow and groundwater recharge conditions during 1992-2004 for existing (baseline) conditions and for conditions representing implementation of flood-control/recharge-enhancement structures.

\section{Data Collection and Compilation}

Input data for the HSPF model include spatial data (land use, geology, soils, topography, and drainage characteristics such as stream-segment length and cross-section data) and meteorologic time-series data (rainfall and pan evaporation). Time series of streamflow and evapotranspiration (ET) data were used for calibration and testing of the model.

Satellite imagery data collected during 2001 were used by USACE to characterize land cover in the study area. The landcover map was refined by MWH Global, Inc., using groundtruthing data collected by the U.S. Department of Agriculture, Natural Resources Conservation Service (NRCS) and from aerial photographs. The resulting land-cover map (C. Coldren, MWH Global, Inc., written commun., 2003) (fig. 4) provided 23 land-cover categories (table 3 ).

The land-cover map (fig. 4), along with geology, soil, and topography information, was used to develop model HRUs. Study area geology (aquifer outcrop areas) (fig. 2) was based on Maclay (1995), Small and Hanson (1994), and Stein and Ozuna (1996). Soil associations were obtained from Bexar, Comal, and Kendall County soil surveys (U.S. Department of Agriculture, 1966; 1984; 1981). Watershed topography (slope) was obtained from USGS 7.5-minute digital elevation models (U.S. Geological Survey, 2003). The digital elevation models also were used to delineate subwatersheds (RCHRES) as part of the model development.

Channel characteristics for each RCHRES (surface area, volume, and discharge as a function of depth) were determined for each of the model segments and entered in HSPF FTABLES (tables of stream-channel parameters). For gaged stream reaches, FTABLE parameters were based on discharge measurements made at USGS streamflow-gaging stations 

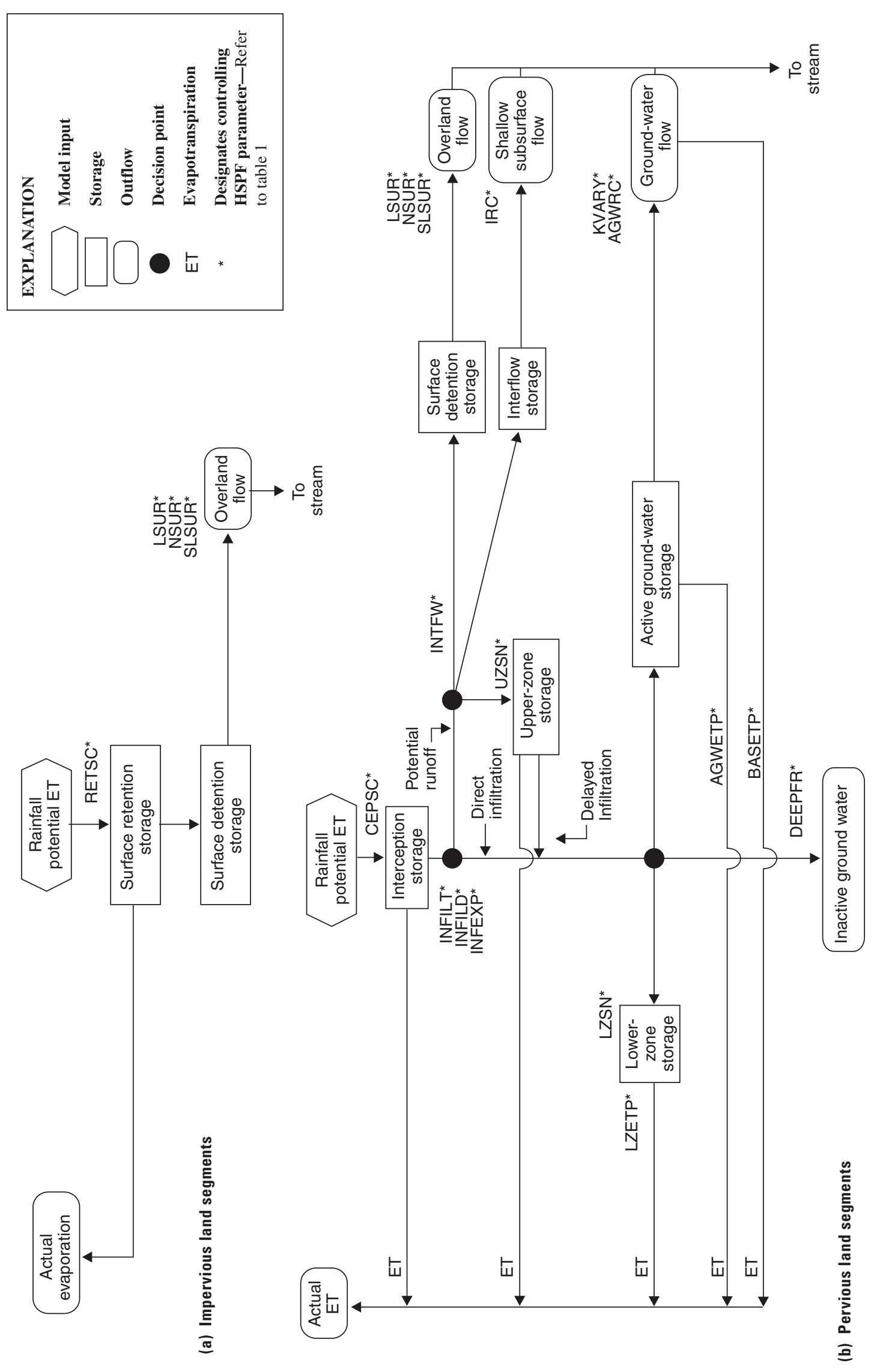

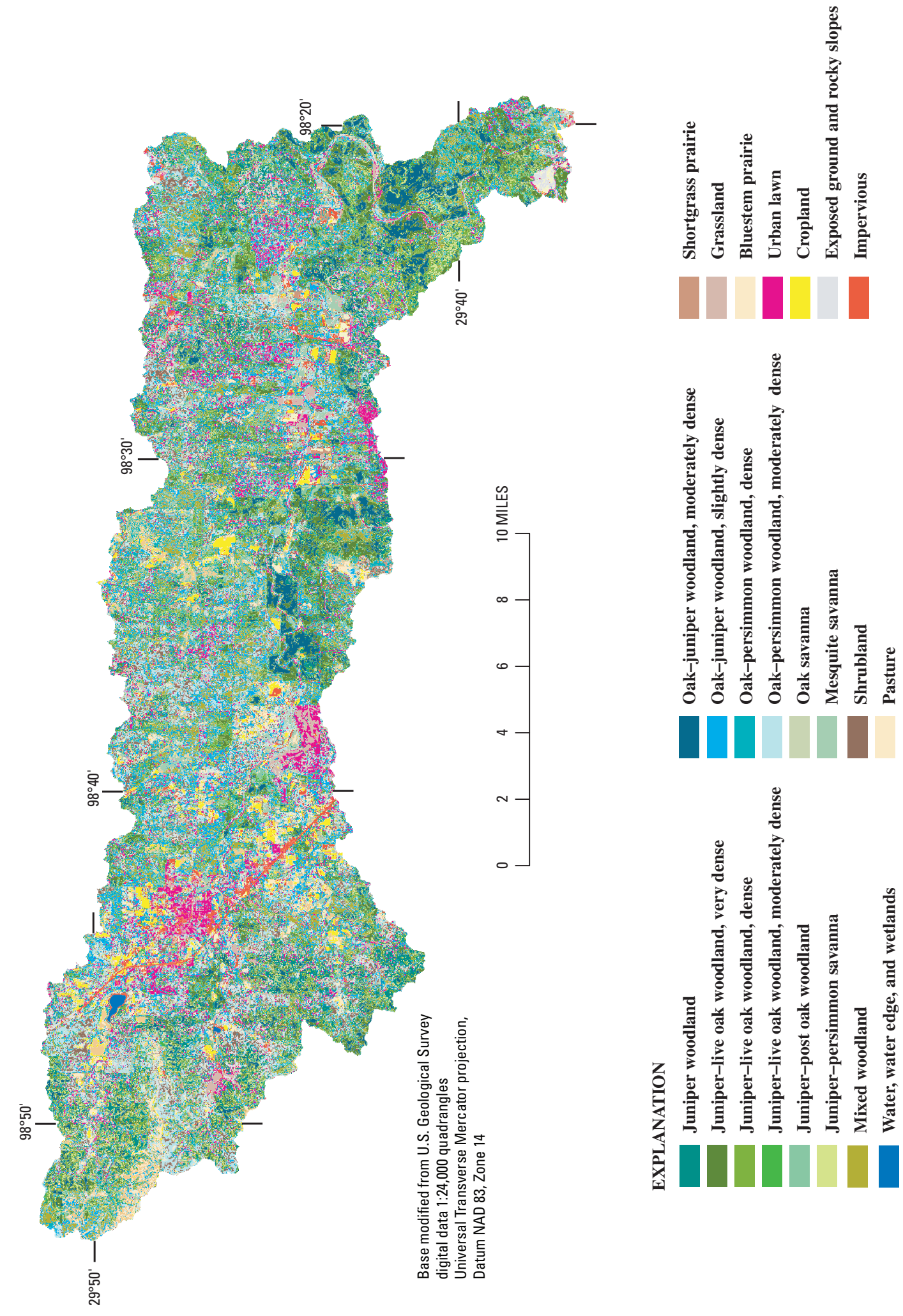

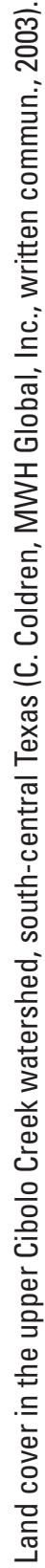


Table 1. Process-related model parameters for the Hydrologic Simulation Program—FORTRAN model (modified from Wicklein and Schiffer, 2002, table 1).

[PERLND, pervious land; IMPLND, impervious land]

\begin{tabular}{|c|c|c|}
\hline Parameter & Description ${ }^{1}$ & Land segment \\
\hline AGWETP & Fraction of available potential evapotranspiration demand that can be met from stored ground water & PERLND \\
\hline BASETP & $\begin{array}{l}\text { Fraction of available potential evapotranspiration demand that can be met from ground-water outflow; } \\
\text { simulates evapotranspiration from riparian vegetation. }\end{array}$ & PERLND \\
\hline CEPSC & Interception storage capacity & PERLND \\
\hline INFEXP & Infiltration equation exponent; controls rate of infiltration decrease as a function of increasing soil moisture & PERLND \\
\hline INFILD & Ratio of maximum and mean infiltration capacities & PERLND \\
\hline INFILT & Index to infiltration capacity of soil; also affects percolation to ground-water zone & PERLND \\
\hline INTFW & Interflow index; controls amount of infiltrated water that flows as shallow subsurface runoff & PERLND \\
\hline LZETP & $\begin{array}{l}\text { Lower-zone evapotranspiration; index value (ranging from } 0 \text { to } 0.99 \text { ) representing density of deep-rooted } \\
\text { vegetation }\end{array}$ & PERLND \\
\hline LZSN & Lower-zone nominal storage; index to soil moisture holding capacity of unsaturated zone & PERLND \\
\hline NSUR & Manning's n for assumed overland flow plane & $\begin{array}{l}\text { PERLND or } \\
\text { IMPLND }\end{array}$ \\
\hline RETSC & Impervious retention storage capacity & IMPLND \\
\hline SLSUR & Slope of assumed overland flow plane & $\begin{array}{l}\text { PERLND or } \\
\text { IMPLND }\end{array}$ \\
\hline UZSN & Upper-zone nominal storage; index to amount of surface storage in depressions and upper few inches of soil & PERLND \\
\hline
\end{tabular}

${ }^{1}$ The user's manual for Hydrologic Simulation Program—FORTRAN (Bicknell and others, 1997) provides a more complete description of each parameter.

(fig. 5; table 4). FTABLE information for ungaged reaches were estimated using surveyed cross-section data collected by the USACE as part of a flood-mapping study (C. Lofton, U.S. Army Corps of Engineers, written commun., 2002).

Meteorologic data compiled and used as input to the watershed model (National Climatic Data Center, 2006) comprised rainfall and pan evaporation (fig. 5; table 4). Table 4 provides information (station name and number, location, type of data, and period of record used) for each data-collection station identified in figure 5. Three National Weather Service (NWS) stations were the primary source of rainfall data. The NWS station at Boerne (site 1, fig. 5) was used for the upstream part of the study area (RCHRES 10-88); the NWS station at Bulverde (site 2, fig. 5) was used for the central part of the study area (RCHRES 90-194); and the NWS station at Randolph Field (site 4, fig 5) was used for the downstream part of the study area (RCHRES 196-212). Data from five additional rain gages (sites $3,7,8,9$, and 18; fig. 5 and table 4) were used to fill in missing record for the three primary rainfall time series. Missing data were filled from the closest station with available data. The NWS stations at Boerne and Bulverde only provide daily data. Because hourly data are required for the model simulations, the Boerne and Bulverde daily data were disaggregated ${ }^{1}$ to hourly data by using the data from the nearest NWS or USGS stations with available hourly data. Pan evaporation data from the NWS station at Sea World, San Antonio (site 5; fig. 5 and table 4) were used for potential evaporation data input to the model. Missing data from the Sea World data set were filled in with data from the NWS station at Canyon Dam (site 6; fig. 5 and table 4) or Sea World average daily values for the appropriate month. Because the NWS data are daily totals, the potential evaporation data were disaggregated ${ }^{1}$ to an average hourly rate for each day.

\footnotetext{
${ }^{1}$ The rainfall and potential evaporation disagregation program are part of the BASINS watershed modeling software package (U.S. Environmental Protection Agency, 2003). Daily rainfall is disaggregated according to the temporal rainfall distribution at one or more nearby hourly stations. Daily potential evaporation is distributed on the basis of latitude and time of year.
} 
Table 2. Basin-related model parameters for the Hydrologic Simulation Program—FORTRAN model.

[PERLND, pervious segment; IMPLND, impervious segment; FTABLE, table of depth, surface area, volume, and discharge for each stream reach]

\begin{tabular}{cll}
\hline $\begin{array}{c}\text { Param- } \\
\text { eter }\end{array}$ & \multicolumn{1}{c}{ Description } & \multicolumn{1}{c}{ Units } \\
\hline AREA & $\begin{array}{c}\text { Drainage area of each } \\
\text { PERLND or IMPLND }\end{array}$ & Acres \\
LEN & Stream reach length & Miles \\
DEPTH & FTABLE depth & Feet \\
SAREA & FTABLE surface area & Acres \\
VOL & FTABLE volume & Acre-feet \\
DISCH & FTABLE discharge & Cubic feet per second \\
\hline
\end{tabular}

Streamflow data for calibrating HSPF runoff were available from two active USGS stations in the study area (sites 10 and 18; fig. 5 and table 4). Station 08183850 Cibolo Creek at Interstate Highway 10 above Boerne measures streamflow in the upper 29 square miles of the study area. Station 08185000 Cibolo Creek at Selma measures streamflow in the entire 274 square miles of the study area. Data from USGS station 08183900 Cibolo Creek near Boerne (site 11; fig. 5 and table 4), discontinued in 1994, were used to test the model calibration. To help quantify streamflow losses to ground water that occur between gaging stations, a series of streamflow measurements were made at selected stations (sites 12-17; fig. 5 and table 4) and at several flow rates along Cibolo Creek during periods of runoff in September 2001 and July 2002 (Gandara, 2003).

Daily discharge from the Boerne wastewater treatment plant was input to the model as equal hourly discharges, disaggregated from daily totals.

Measured ET data from an undeveloped rangeland watershed were obtained from stations in the Honey Creek watershed north of and adjacent to the Cibolo Creek Basin (sites 19 and 20; fig. 5 and table 4). These data were collected from an area in the Trinity aquifer outcrop (Glen Rose Limestone) with moderate density of juniper and oak vegetation. Data were available for March-December 2002. These data were daily totals and were used to test HSPF ET simulations. All USGS data used for modeling are in the National Water Information System (U.S. Geological Survey, 2006).

\section{Model Development}

The HSPF model of upper Cibolo Creek was developed by (1) defining subwatersheds for the study area; (2) classifying unique HRUs on the basis of combinations of land cover, geology, soil, and slope; and (3) determining initial (uncalibrated) values of associated model parameters. Initial estimates of parameters were determined or estimated from default values, previous studies, available observed data, and results of simulations from an ecological model, Ecological Dynamics Simulations (EDYS) (Price and others, 2001). The EDYS model was developed by MWH Global, Inc., for the USACE Cibolo Creek project.

Table 3. Land-cover categories and areas for the upper Cibolo Creek watershed, south-central Texas.

\begin{tabular}{|c|c|c|}
\hline $\begin{array}{l}\text { Land-cover category } \\
\text { (fig. 4) }\end{array}$ & $\begin{array}{c}\text { Area } \\
\text { (acres) }\end{array}$ & $\begin{array}{c}\text { Percentage } \\
\text { of total } \\
\text { watershed } \\
\text { area }\end{array}$ \\
\hline Juniper woodland & 5,397 & 3.1 \\
\hline Juniper-live oak woodland, very dense & 6,420 & 3.7 \\
\hline Juniper-live oak woodland, dense & 14,312 & 8.2 \\
\hline Juniper-live oak woodland, moderately dense & 14,115 & 8.1 \\
\hline Juniper-post oak woodland & 1,947 & 1.1 \\
\hline Oak-juniper woodland, moderately dense & 29,649 & 16.9 \\
\hline Oak-juniper woodland, slightly dense & 11,861 & 6.8 \\
\hline Oak-persimmon woodland, dense & 5,217 & 3.0 \\
\hline Oak-persimmon woodland, moderately dense & 9,250 & 5.3 \\
\hline Mixed woodland & 8,138 & 4.6 \\
\hline Juniper-persimmon savanna & 2,587 & 1.5 \\
\hline Oak savanna & 5,197 & 3.0 \\
\hline Mesquite savanna & 3,888 & 2.2 \\
\hline Shrubland & 4,703 & 2.7 \\
\hline Grassland & 4,743 & 2.7 \\
\hline Bluestem prairie & 11,433 & 6.5 \\
\hline Shortgrass prairie & 1,684 & 1.0 \\
\hline Pasture & 4,622 & 2.6 \\
\hline Cropland & 5,835 & 3.3 \\
\hline Urban lawn & 11,066 & 6.5 \\
\hline Exposed ground and rocky slopes & 2,178 & 1.2 \\
\hline Water, water edge, and wetlands & 3,939 & 2.2 \\
\hline Impervious & 6,629 & 3.8 \\
\hline Total & 175,098 & 100 \\
\hline
\end{tabular}




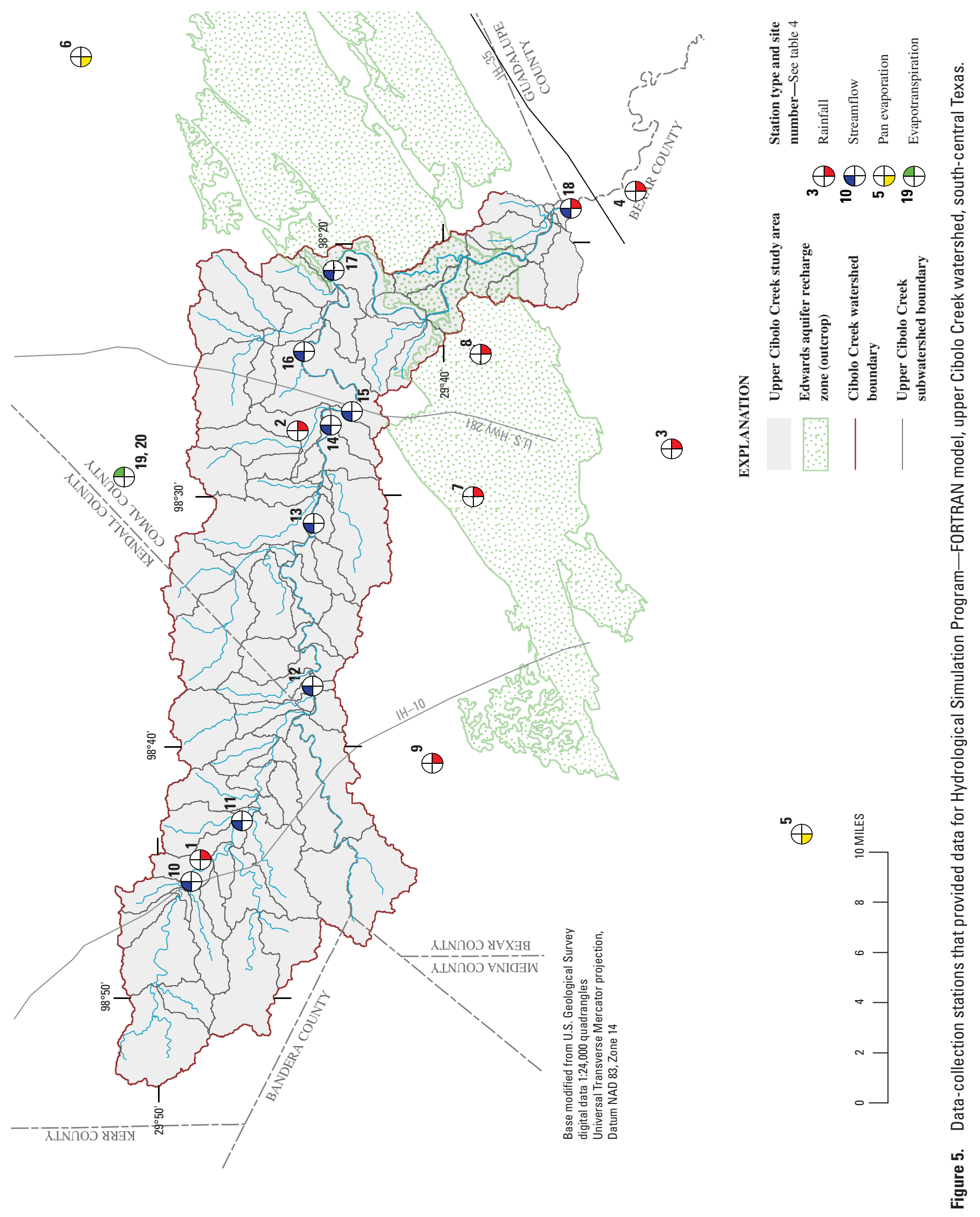


Table 4. Data-collection stations that provided data for the Hydrologic Simulation Program—FORTRAN model, upper Cibolo Creek watershed, south-central Texas.

[dd, degrees; mm, minutes; ss, seconds; NWS, National Weather Service; --, not available; USGS, U.S. Geological Survey]

\begin{tabular}{|c|c|c|c|c|c|}
\hline $\begin{array}{c}\text { Site } \\
\text { number } \\
\text { (fig. 5) }\end{array}$ & Station name and number & $\begin{array}{l}\text { Latitude } \\
\text { (ddmmss) }\end{array}$ & $\begin{array}{l}\text { Longitude } \\
\text { (ddmmss) }\end{array}$ & Type of data & $\begin{array}{l}\text { Period of } \\
\text { record used }\end{array}$ \\
\hline 2 & NWS station 411215 near Bulverde, Texas & $29^{\circ} 45^{\prime}--"$ & $98^{\circ} 27^{\prime}--"$ & Rainfall & 1997-2002 \\
\hline 4 & NWS station 417422 at Randolph Field, Texas & $29^{\circ} 33^{\prime}--"$ & $98^{\circ} 18^{\prime}--"$ & Rainfall & 1992-2004 \\
\hline 5 & NWS station 418169 at Sea World, San Antonio, Texas & $29^{\circ} 27^{\prime}--"$ & $98^{\circ} 42^{\prime}--"$ & Pan evaporation & 1997-2004 \\
\hline 8 & $\begin{array}{l}\text { USGS partial-record station 08178627 Elm Waterhole } \\
\text { Creek Tributary at San Antonio, Texas }\end{array}$ & $29^{\circ} 38^{\prime} 48^{\prime \prime}$ & $98^{\circ} 24^{\prime} 23^{\prime \prime}$ & Rainfall & $2001-02$ \\
\hline 9 & $\begin{array}{l}\text { USGS station } 08180945 \text { Leon Creek at Scenic Loop Road } \\
\text { near Leon Springs, Texas }\end{array}$ & $29^{\circ} 40^{\prime} 32^{\prime \prime}$ & $98^{\circ} 40^{\prime} 33^{\prime \prime}$ & Rainfall & $2001-02$ \\
\hline 10 & $\begin{array}{l}\text { USGS station } 08183850 \text { Cibolo Creek at Interstate Highway } \\
10 \text { above Boerne, Texas }\end{array}$ & $29^{\circ} 48^{\prime} 52^{\prime \prime}$ & $98^{\circ} 45^{\prime} 12^{\prime \prime}$ & Streamflow & 1996-2004 \\
\hline 11 & USGS station 08183900 Cibolo Creek near Boerne, Texas & $29^{\circ} 46^{\prime} 26^{\prime \prime}$ & $98^{\circ} 41^{\prime} 50^{\prime \prime}$ & Streamflow & 1992-1994 \\
\hline 15 & $\begin{array}{l}\text { USGS partial-record station } 08183995 \text { Cibolo Creek at U.S. } \\
\text { Highway } 281 \text { near Bulverde, Texas }\end{array}$ & $29^{\circ} 43^{\prime} 09^{\prime \prime}$ & $98^{\circ} 26^{\prime} 36^{\prime \prime}$ & Streamflow & $2001-02$ \\
\hline 16 & $\begin{array}{l}\text { USGS partial-record station } 08184050 \text { Cibolo Creek at } \\
\text { Smithson Valley Road near Bulverde, Texas }\end{array}$ & $29^{\circ} 44^{\prime} 54^{\prime \prime}$ & $98^{\circ} 24^{\prime} 28^{\prime \prime}$ & Streamflow & $2001-02$ \\
\hline 17 & $\begin{array}{l}\text { USGS partial-record station } 08184300 \text { Cibolo Creek at } \\
\text { Farm Road } 1863 \text { below Bulverde, Texas }\end{array}$ & $29^{\circ} 43^{\prime} 58^{\prime \prime}$ & $98^{\circ} 21^{\prime} 23^{\prime \prime}$ & Streamflow & $2001-02$ \\
\hline 18 & USGS station 08185000 Cibolo Creek at Selma, Texas & $29^{\circ} 35^{\prime} 38^{\prime \prime}$ & $98^{\circ} 18^{\prime} 39^{\prime \prime}$ & $\begin{array}{l}\text { Rainfall and } \\
\text { streamflow }\end{array}$ & 1992-2004 \\
\hline 19 & $\begin{array}{l}\text { USGS station } 295104098285900 \text { Honey Creek reference } \\
\text { evapotranspiration site near Spring Branch, Texas }\end{array}$ & $29^{\circ} 51^{\prime} 04^{\prime \prime}$ & $98^{\circ} 28^{\prime} 59^{\prime \prime}$ & Evapotranspiration & 2002 \\
\hline 20 & $\begin{array}{l}\text { USGS station } 295102098283200 \text { Honey Creek treatment } \\
\text { evapotranspiration site near Spring Branch, Texas }\end{array}$ & $29^{\circ} 51^{\prime} 02^{\prime \prime}$ & $98^{\circ} 28^{\prime} 32^{\prime \prime}$ & Evapotranspiration & 2002 \\
\hline
\end{tabular}


The HSPF model was configured by dividing the study area into 80 subwatersheds. As noted previously, these subwatersheds correspond to HSPF stream reaches (RCHRESs) (fig. 6). Considerations in developing the stream reach configuration include (1) defining reaches with flows such that travel times approximate the model simulation time step (1 hour); (2) defining reaches with homogeneous channel properties, such as slope and conveyance; and (3) locating outlets of subwatersheds at important points, such as gaging stations, tributary confluence, outcrop boundaries, and inflows from sources or outflows to sinks.

Pervious and impervious HRUs were classified as such according to land use, geology, soil, and slope characteristics. Geology categories include the Glen Rose Limestone of the Trinity aquifer outcrop (relatively low to moderate permeability); the Edwards Group and Georgetown Formation of the Edwards aquifer outcrop (relatively high permeability); and upper confining unit of the Edwards aquifer (relatively low to moderate permeability) (Small and Hanson, 1994). The Glen Rose Limestone category was subdivided into two categories largely on the basis of soil and runoff characteristics. Glen Rose-shallow soil (largely composed of Tarrant-Brackett association or similar soils) was assigned to the upstream part of the study area and includes PERLNDs in subwatersheds (RCHRES) 10-88. Glen Rose-deep soil (Crawford-Bexar Association) was assigned to PERLNDs in RCHRES 90-176. RCHRES 180-190 transition from Glen Rose Limestone to Edwards Group and Georgetown Formation. Soil characteristics of PERLNDs in geologically transitional RCHRES 180190 are similar to PERLNDs in RCHRES 90-176. Edwards Group and Georgetown Formation characterize RCHRES 192-196. PERLNDs associated with RCHRES 198 and 206 contain rocks of the Edwards Group and Georgetown Formation, and the Austin Group, one of several geologic units of the upper confining unit of the Edwards aquifer. PERLNDs in RCHRES 200-204 and 208-212 contain rocks of the Austin Group. Soil in RCHRES 192-212 is characterized as mostly Crawford-Bexar Association.

Based on combinations of land cover, geology, and soil type, 275 pervious HRU types are possible. The average landsurface slope in a subwatershed generally was applied to all pervious HRUs in that subwatershed. Impervious area was included as a single impervious HRU type (except for changes in surface slope and retention storage), with similar hydrologic properties across the entire watershed. In HSPF terminology, HRUs correspond to PERLND and IMPLND segments.

Three rainfall time series were developed, representing input to the upper, central, and lower parts of the study area. The upstream area includes HRUS associated with RCHRES 10-88; the central area includes HRUs associated with RCHRES 90-194; and the downstream area includes HRUs associated with RCHRES 196-212. A single potential evaporation time series was applied to the entire study area.

In the study area, substantial amounts of runoff are lost to stream-channel infiltration (ground-water recharge) before flow reaches the study area outlet. HSPF does not include pro- cess parameters or specific features to account for streamflow losses. Instead, these losses were accounted for in the model as water withdrawals from the stream reaches. The withdrawals were established in the stream reach (FTABLE) configuration as a function of stream discharge or stream volume. These withdrawals were routed to ground-water recharge.

Model development was completed by assigning initial values to process-related HSPF parameters. These values collectively represented a starting point for calibration of the model by iterative parameter adjustment. Initial values of parameters related to streamflow and ground-water recharge were based on previous HSPF studies in the region (Brown and Raines, 2002; Ockerman, 2002). Data from the EDYS ecological model (C. Coldren, MWH Global, Inc., written commun., 2002) also were used to develop initial values for ET- and interception-related process parameters (primarily CEPSC, LZETP, LZSN, and UZSN).

The HSPF software (version 12) limits a single simulation run to no more than 500 model operations. Each separate PERLND, IMPLND, and RCHRES model element is considered an operation. Because of concerns about exceeding operation limits, the Cibolo Creek HSPF model was run as two separate models. The upstream part of the model includes RCHRES 10-88 and associated PERLNDs and IMPLNDs. The downstream part of the model includes all model elements downstream of RCHRES 88. To run a simulation for the entire watershed, the separate models were run sequentially, and the ouput from the upstream model was used as input to the downstream model.

\section{Streamflow Calibration}

A primary goal of watershed model calibration was to match model-simulated streamflow to measured streamflow. Criteria such as error in total streamflow volume for the calibration period, low-flow and high-flow distribution, and error in peak flows were used to evaluate how well the simulated streamflow represented actual streamflow.

Streamflow data collected at USGS station 08183850 Cibolo Creek at Interstate Highway 10 above Boerne were used to calibrate model streamflow for the part of the study area upstream from the station (RCHRES 10-28). Also, model parameters obtained from this calibration were applied to HRUs in RCHRES 30-88. Data collected at USGS station 08185000 Cibolo Creek at Selma were used to calibrate the rest of the study-area model because streamflow from the entire study area is measured at this site. Data from stations 08183850 and 08185000 for 1997-2000 were used for calibration. Data for 2001-04 were used to test the model calibration. Data from discontinued USGS station 08183900 Cibolo Creek near Boerne also were used to test model calibration for the period 1992-94. Model calibration and testing results are shown in table 5 (at end of report).

Calibration and testing results for total flow volumes, total of highest 10 percent of flows, total of lowest 50 percent of flows, and average of selected storm peaks are shown in 


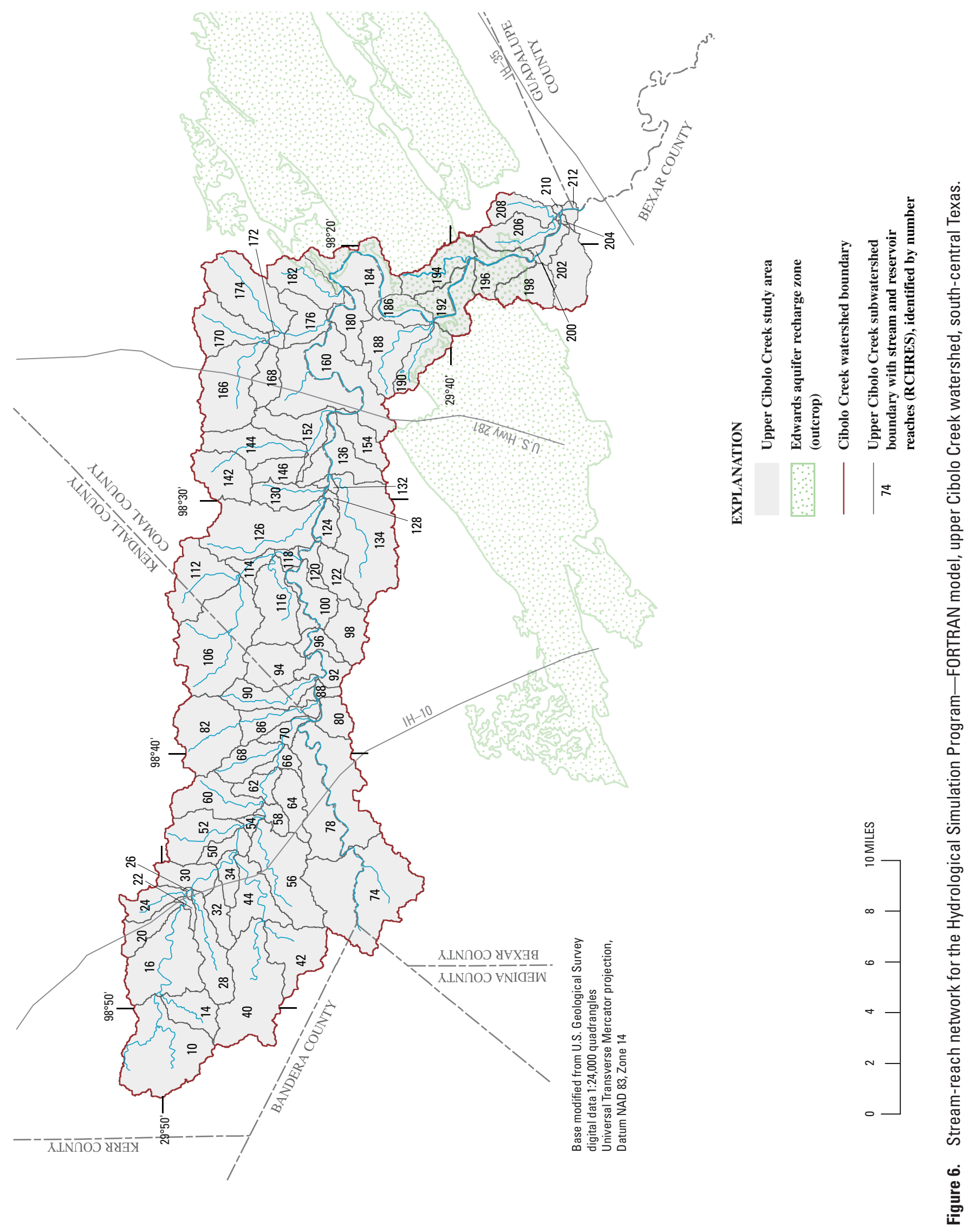


table 5. The error in simulated streamflow volume (difference between simulated and gaged streamflow) at the outlet of the study-area watershed (USGS streamflow-gaging station 08185000 Cibolo Creek at Selma) for 1997-2004 was about 2 percent. Simulation errors generally were within limits (table 5) recommended by Donigian (2002, p. 14) for most categories at all gaging stations. The exception was lowest 50 percent of flows at station 08183850 . The simulated lowest 50 percent of flows for that station during the 2001-04 testing period were 15.1 percent less than the measured. The measured total of lowest 50 percent of daily flows at station 08183850 represents only 4 percent of the measured total flow volume during the 1997-2004 period. The difference between measured and simulated totals of lowest 50 percent of daily flows at this site represents less than 1 percent of the total flow volume.

Simulated flows at all three gaging stations were evaluated graphically by comparing measured and simulated daily time series, exceedance-probability curves, and scatter plots. General agreement between the measured and simulated exceedance-probability curves indicates adequate calibration over the range of flow conditions (figs. 7-9).

Donigian and others (1984) present general guidelines for evaluating HSPF calibrations. For annual streamflow volumes, model calibration is considered very good when the error is less than 10 percent, good when the error is 10 to 15 percent, and fair when the error is 15 to 25 percent. By these guidelines, calibration results for annual flow volumes at all three gaging stations are considered very good.

\section{Evapotranspiration and Interception Testing}

Another goal of the watershed model calibration was to accurately simulate the overall water budget in the watershed, including ground-water recharge and ET. Model simulations of ground-water recharge cannot be compared with measured values because diffuse recharge (direct infiltration of rainfall through the soil layers to the water table), especially in a faulted karst environment such as Cibolo Creek, generally cannot be measured directly ${ }^{2}$. Thus, model simulations, or estimates, of ground-water recharge depend on accurate model representations of the remaining water-budget components not associated with ground-water recharge (streamflow, ET, and changes in soil-water storage over the simulation period). Annual streamflow in Cibolo Creek (measured at station 08185000 Cibolo Creek at Selma) usually constitutes less than 10 percent of annual rainfall, and changes in soil-water storage (as a percentage of the water budget) were considered minor, especially over relatively long simulation periods. Therefore, ET plus ground-water recharge accounts for about 90 percent of the rainfall on the watershed. Errors in ET simulations can result in substantial errors in diffuse ground-water recharge estimates.

\footnotetext{
${ }^{2}$ Recharge in the study area occurs as diffuse recharge and as streamchannel infiltration. Although diffuse recharge could not be measured, streamchannel infiltration losses were measured indirectly during the study.
}

ET, computed from the Bowen-ratio energy balance method (Atmospheric Radiation Measurement Program, 2003), was available for March-December 2002 from the Honey Creek watershed (W.H. Asquith, U.S. Geological Survey, written commun., 2002) for comparison with simulated ET for the study area. Simulated ET for the most similar geology and land cover (PERLND type Glen Rose Limestone, juniper-live oak woodland, moderately dense) was compared with the measured ET (table 6, at end of report). Monthly simulation error ranged from -32 to 47 percent. ET simulations in the study area are relatively sensitive to rainfall. Differences in rainfall between the upper Cibolo Creek watershed and the Honey Creek watershed might contribute to some of the simulation error. Long-term error was less: During the entire 10-month comparison period, simulated ET was 4 percent greater than measured ET.

Another test of HSPF ET simulations involved analysis of the simulated canopy interception of juniper woodland land cover. A substantial part of the total ET in juniper communities occurs as direct evaporation of intercepted rainfall. The Texas Agricultural Experiment Station (TAES), Uvalde, Tex., studied interception water loss at 10 sites in the Edwards aquifer recharge area (Owens and others, 2001). Among the 10 study sites, interception water loss to evaporation accounted for 43 percent of rainfall. This interception percentage likely was higher than that for the vegetation categories used for the Cibolo Creek model because the TAES study results apply to individual juniper trees or the equivalent of 100percent juniper density. The results of the TAES study were useful for comparing with HSPF-simulated ET for juniper woodland land cover and for evaluating the HSPF model partitioning of simulated ET losses between interception losses and soil and lower zone ET. During 1997-2004, HSPF-simulated interception ET was 39 percent of rainfall for juniper woodland land cover. HSPF partitioning of ET losses between canopy interception evaporation and soil and plant ET appear reasonable for the juniper woodland land-cover categories.

As a result of calibration and testing, a set of HSPF process-related parameters were obtained for the study area (tables 7 and 8, at end of report). This parameter set was used to simulate streamflow and recharge for the study area for 1992-2004.

\section{Simulated Streamflow, 1992-2004}

The upper Cibolo Creek HSPF model has the capability to simulate streamflow at the outlet of each stream and reservoir (RCHRES) segment (fig. 6). Streamflows at five selected sites in the study watershed were compared to demonstrate the effects of stream-channel infiltration losses. Table 9 (at end of report) lists average annual streamflow per unit area of contributing watershed, expressed in inches per year, for 1992-2004 at each selected site. The most upstream site had the greatest runoff ( 8.90 inches per year) and the most 

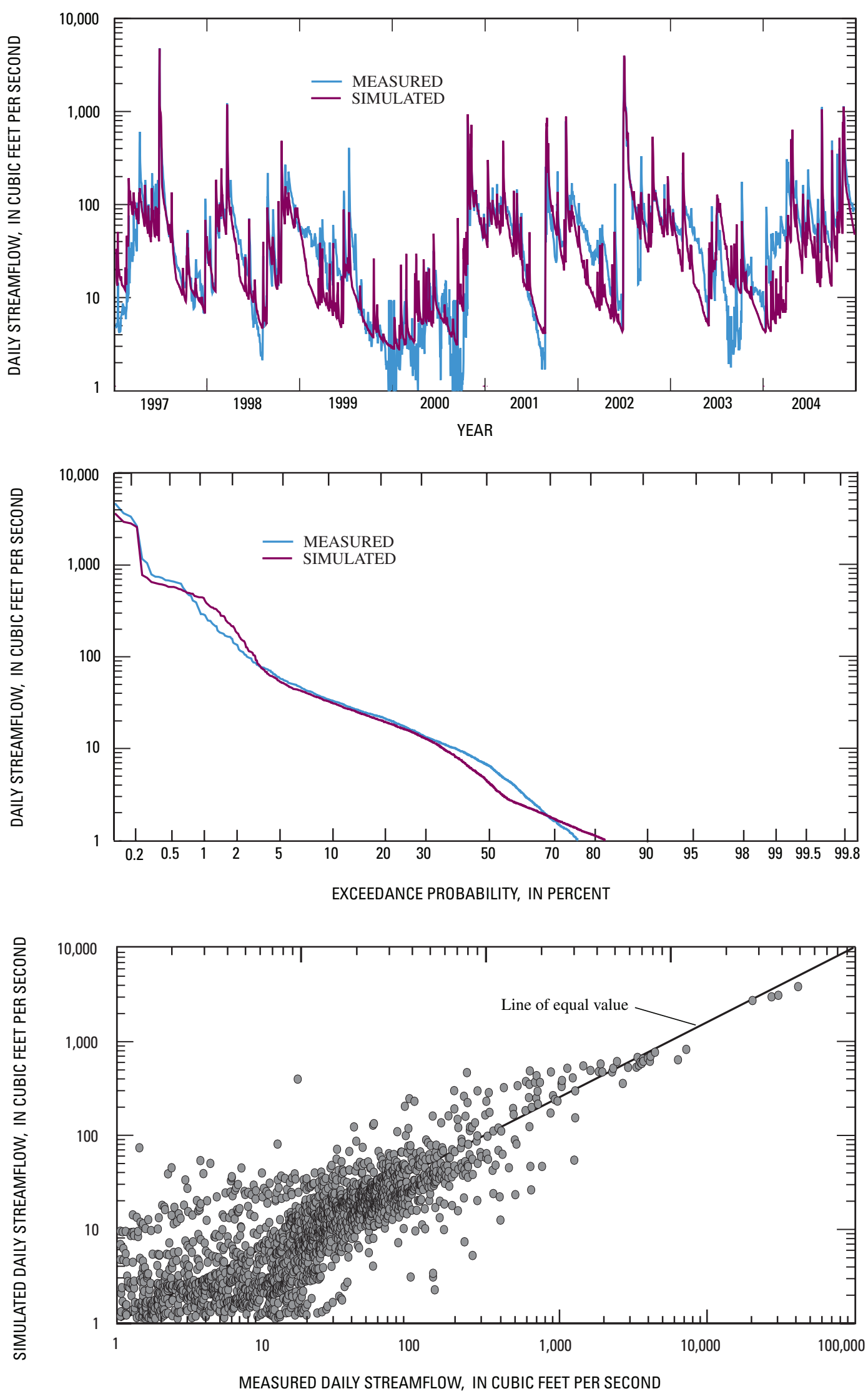

Figure 7. Measured and simulated daily streamflow at station 08183850 Cibolo Creek at Interstate Highway 10 above Boerne, Texas, 1997-2004. 

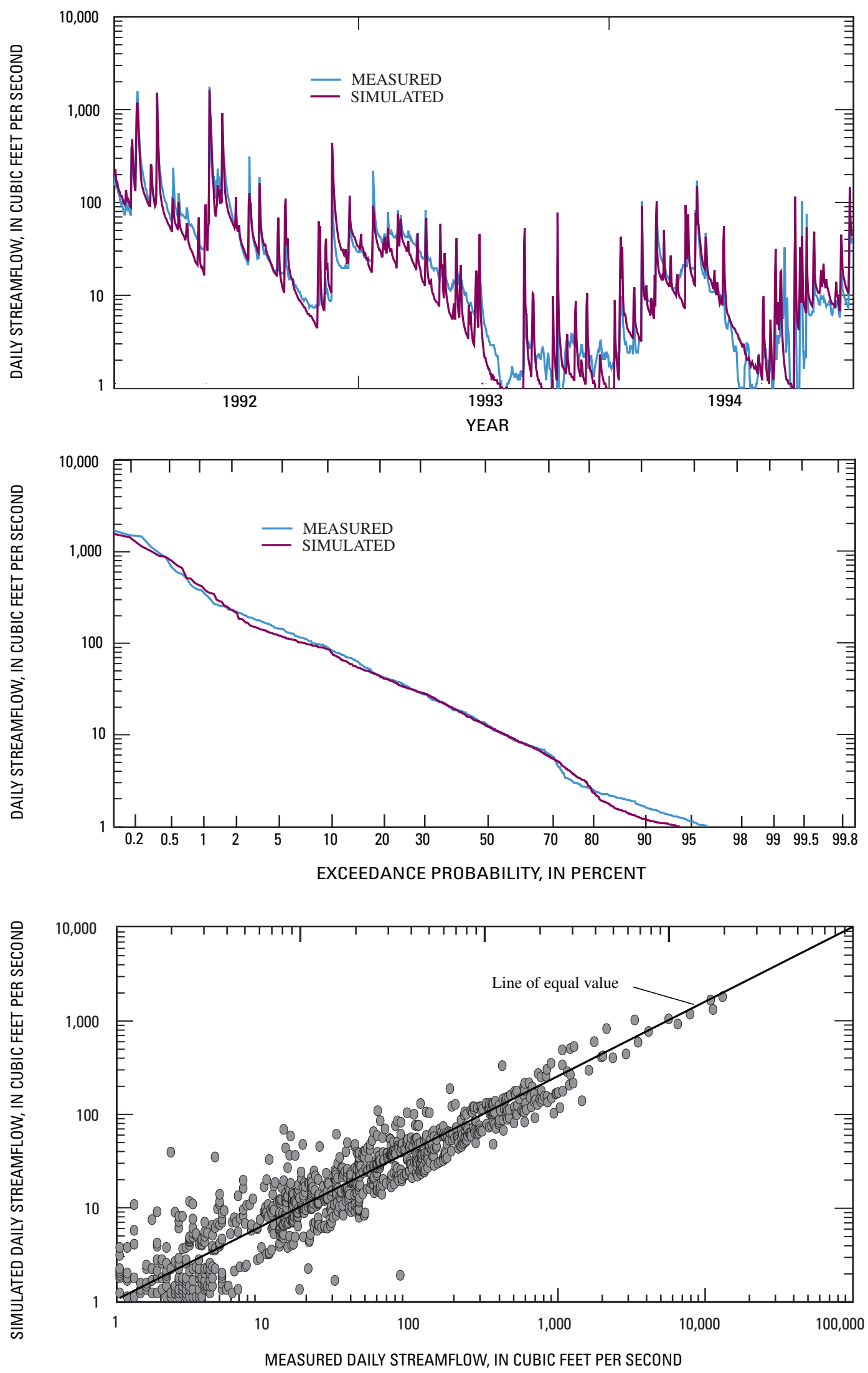

Figure 8. Measured and simulated daily streamflow at station 08183900 Cibolo Creek near Boerne, Texas, 1992-94. 

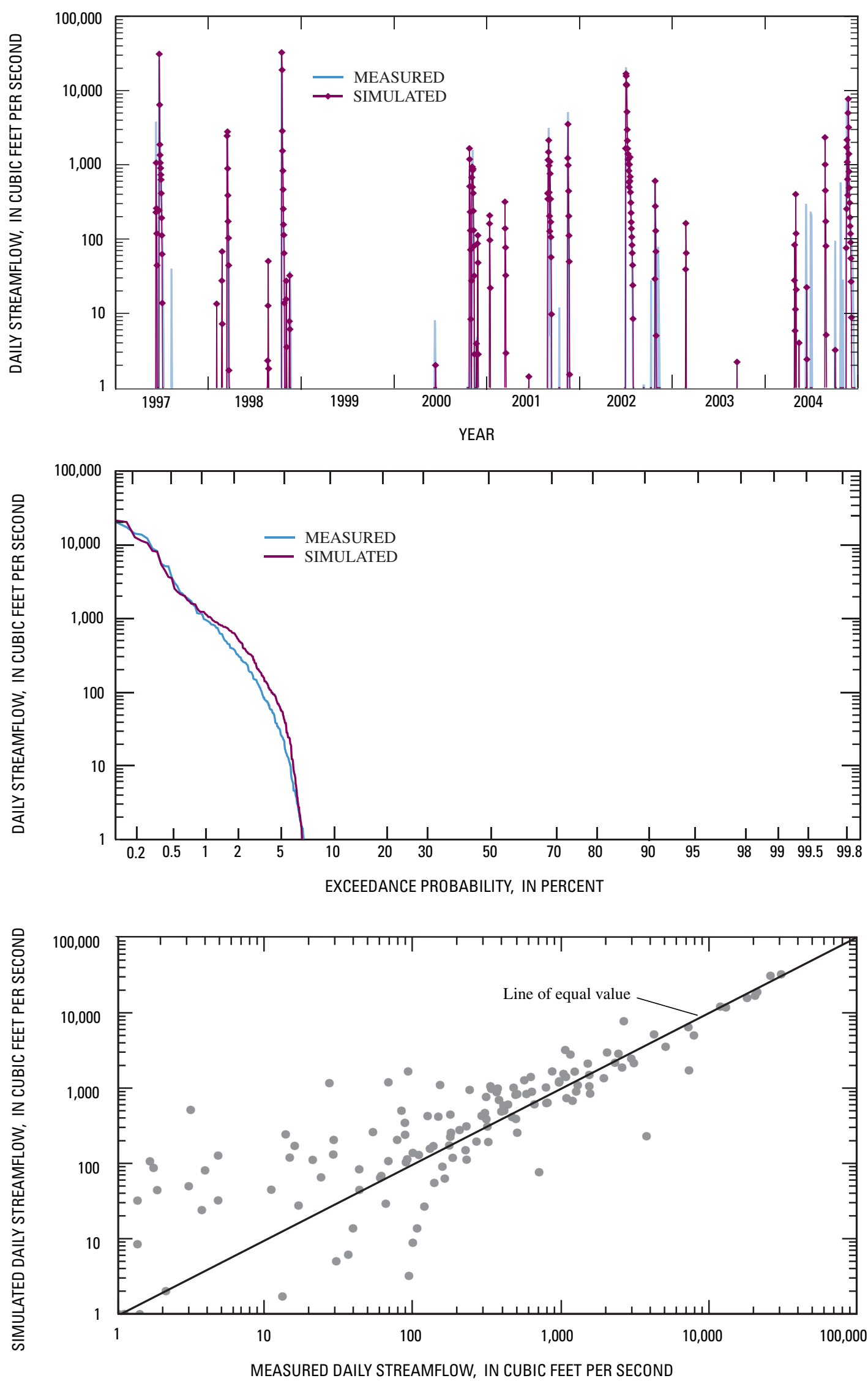

Figure 9. Measured and simulated daily streamflow at station 08185000 Cibolo Creek near Selma, Texas, 1997-2004. 
downstream site had the least runoff (3.22 inches per year). Runoff consistently decreased downstream primarily because of stream-channel infiltration losses along Cibolo Creek.

Simulations indicate that during 1992-2004 about 56 percent of runoff (water leaving PERLNDs and IMPLNDs as surface runoff, interflow, or base flow and reaching the channel as streamflow) was lost to channel infiltration: 7.24 inches per year of runoff (including 0.05 inch per year of treated wastewater discharge) reached Cibolo Creek, but only 3.22 inches per year exited the study area. Average annual rainfall on the study area during 1992-2004 was 37.43 inches. Therefore, simulated streamflow exiting the study area was 8.6 percent of the rainfall.

Streamflow in the watershed is highly variable and dominated by large storms. During the 1992-2004 study period, 61 percent of the streamflow at station 08185000 Cibolo Creek at Selma occurred during three large storms (June 1997, October 1998, and July 2002). During 2002, 11.10 inches of runoff exited the study area, despite the fact that no runoff occurred in 8 months during 2002. During calendar years 1996, 1999, and 2003, no flow was measured at the Selma station. Runoff during 1992-2004 was greater than average and represented a greater-than-normal percentage of rainfall. The 1946-2004 average annual runoff at the Selma station was 1.15 inches, which is less than 5 percent of average annual rainfall in the upper Cibolo Creek watershed.

\section{Estimated Ground-Water Recharge, 1992-2004}

HSPF simulations were used to estimate quantities and locations of ground-water recharge during 1992-2004. For the entire study watershed, average ground-water recharge was 79,800 acre-feet per year, or 5.47 inches per year (about 15 percent of rainfall) (table 10, at end of report). Annual recharge ranged from 14,500 acre-feet (0.99 inch) in 1999 to 196,000 acre-feet (13.43 inches) in 1992. Overall in the study area, most recharge (about 74 percent) occurred as stream-channel infiltration (table 11, at end of report). Diffuse recharge accounted for the remaining 26 percent. About 77 percent $(61,500$ acre-feet per year) of the ground-water recharge occurred in the Trinity aquifer outcrop; about 13 percent $(10,200$ acre-feet per year) occurred in the area of transition from the Trinity aquifer outcrop to the Edwards aquifer outcrop; about 6.4 percent $(5,130$ acre-feet per year) occurred in the Edwards aquifer recharge zone (outcrop); and about 3.6 percent $(2,940$ acre-feet per year) occurred in the area of transition from the Edwards aquifer recharge zone (outcrop) to Edwards aquifer upper confining unit and the area of upper confining unit (the two areas combined).

Ground-water recharge also was greatly influenced by large storms. During 1992-2004, 11 percent (53.90 inches) of the total 13-year rainfall and 16 percent $(178,000$ acre-feet) of the total 13-year ground-water recharge occurred during the three large storms (June 1997, October 1998, and July
2002). During 1999, a dry year with about 16 inches of rainfall and no measured runoff at the watershed outlet, recharge in the watershed amounted to only 14,500 acre-feet (0.99 inch) compared with 196,000 acre-feet (13.43 inches) during 1992, a relatively wet year with about 54 inches of rainfall.

\section{Simulated Streamflow and Estimated Ground- Water Recharge With Implementation of Flood- Control/Recharge-Enhancement Structures}

Local water-resource agencies have expressed interest in constructing structures (dams) along Cibolo Creek (as well as other streams that cross the Edwards aquifer recharge zone) to provide flood control and to potentially increase recharge through increased stream-channel infiltration (San Antonio River Authority, 1996; San Antonio Water System, 2006). The structures would potentially increase recharge in two ways: (1) Structures constructed on the stream upstream from or in the upper reaches of a recharge area (a stream reach where streamflow infiltrates to the underlying aquifer) would function as detention structures, holding back floodwater for a limited period and releasing water at a slower flow rate. The slower release would cause slower streamflow recession and thus more time for stream-channel infiltration, resulting in increased recharge; and (2) structures constructed on the stream in an area of high infiltration, or relatively high recharge capacity, would function as retention structures, holding back floodwater for an extended period of time, allowing for direct infiltration of impounded water to the aquifer. Some structures possibly might function in both ways.

The calibrated Cibolo Creek HSPF model was used to simulate streamflow and recharge for a set of scenarios that included various individual structures and combinations of structures at several sites in the watershed. The purpose of the simulations was to determine whether such structures could potentially provide flood control (reduce flood peaks) and increase recharge in the upper Cibolo Creek watershed. The locations and sizes of the structures were determined by considering recommendations from the study cooperators: (1) Structures should be located in areas that provide recharge primarily to the Edwards aquifer, with recharge to the Trinity aquifer as a secondary benefit; (2) structures should be located at sites that provide flood-peak reduction in the downstream part of the study area (near the Selma station); and (3) structures should be located at sites that meet some minimum requirements for a suitable structure location-these requirements include (a) reasonable trade-off between large storage volume and small inundation area, and (b) avoiding inundation of developed areas.

Figure 10 shows the locations of structures and impoundment areas simulated. Table 12 (at end of report) shows corresponding structure specifications such as dam height, spillway height, storage volume, and spillway capacity. Seven 


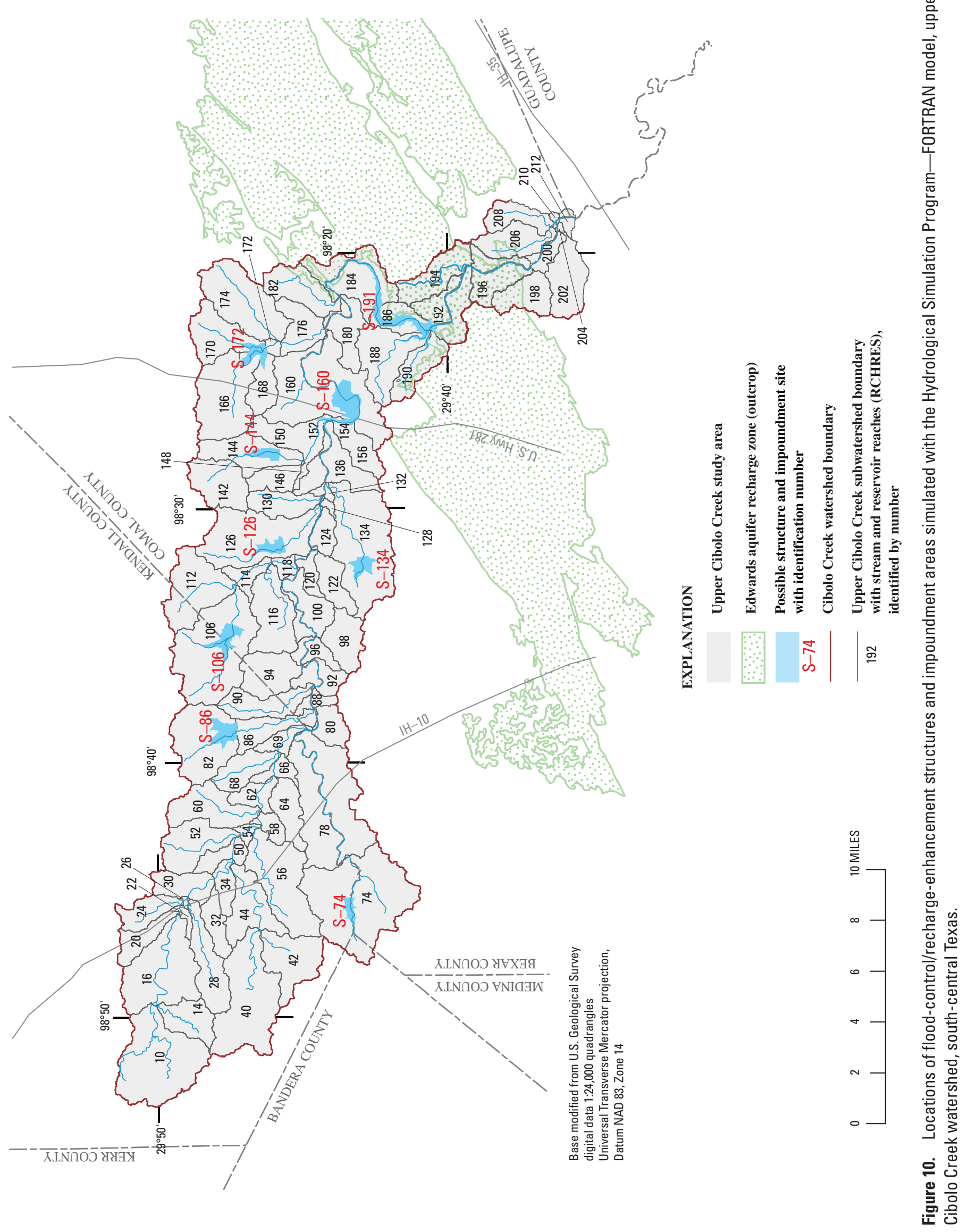


of the nine structures were on tributaries of Cibolo Creek. The two largest structures (S-160 and S-191) are on the main stem of Cibolo Creek. Structure S-160 is on the Trinity aquifer outcrop and $\mathrm{S}-191$ is at the transition from the Trinity aquifer outcrop to the Edwards aquifer outcrop.

HSPF simulations were run for each of the scenarios listed in table 13 (at end of report). Results of the simulations comprise changes in simulated peak discharge (at station 08185000) during the October 1998 storm (historic peak) and changes in simulated channel infiltration (recharge) in the Trinity and Edwards aquifer outcrops during 1992-2004.

Simulations of individual tributary structures show relatively small effects on flood-peak reduction and groundwater recharge enhancement. All simulated tributary structures were on the Trinity aquifer outcrop and increased recharge to the Trinity aquifer. Generally, stream-channel infiltration to the Edwards aquifer was slightly decreased because increased recharge to the Trinity aquifer resulted in less water available to flow downstream across the Edwards aquifer outcrop. Simulations with the two large main-stem structures, S-160 and S-191, showed a greater effect on flood-peak reduction and recharge enhancement than the tributary structures. Individually, S-160 and S-191 simulations resulted in decreases of the October 1998 peak discharge of about 25 percent and 17 percent, respectively. The S-160 structure increased recharge primarily to the Trinity aquifer, and the $S-191$ structure increased recharge to the Edwards aquifer.

A simulation comprising both main-stem structures, S-160 and S-191, resulted in substantial peak-flow reduction (37 percent) and an increase in recharge in stream channels. With this scenario, stream-channel recharge increased 6.6 percent in the Trinity aquifer outcrop and 12.6 percent in the Edwards aquifer outcrop. Simulation of a combination of three tributary structures (S-106, S-126, and S-144) resulted in a peak flow decrease of about 11 percent (October 1998 storm at station 08185000$)$. A small increase (1.3 percent) in Trinity aquifer recharge was offset by a decrease ( 2.0 percent) in Edwards aquifer recharge.

Simulations with combinations of tributary structures and main-stem structures did not produce results substanially different than with the main-stem structures alone. The main-stem structures were more effective than the tributary structures for two reasons: First, the main-stem structures have larger storage capacity and are more effective at detaining and releasing water more slowly along the aquifer outcrop streams, potentially increasing recharge. Second, with much larger contributing drainage areas, the main-stem structures receive larger volumes of inflow and thus affect much greater volumes of streamflow than the tributary structures.

\section{Model Limitations and Applications}

Limitations in the available rainfall data are likely the most serious source of simulation error and uncertainty for the Cibolo Creek study. Streamflow and recharge in the water- shed are highly dependent on the occurrence of large storms. Data from the available network of rain gages do not always adequately represent the spatial and temporal variability of rainfall in the watershed. For example, a storm in June 1997 contributed more than 25 percent of the total streamflow (at station 08185000 Cibolo Creek at Selma) during the 19922004 period. Simulated streamflow and peak flows during this storm were less than measured flows, likely because of an underestimation of rainfall totals in the upstream part of the study area. Streamflow also is highly dependent on rainfall intensity. Two of three primary rain gages used for the model simulations were daily rain gages. The daily totals were disagregated to hourly values on the basis of data from the nearest available gages, which usually were outside the watershed. Thus, some uncertainty in rainfall intensity exists for simulations run with this model.

Simulation errors also are generated because peak discharges reported for the USGS streamflow-gaging stations in the study area were not measured directly but were obtained by indirect methods (Benson and Dalrymple, 1967). Because indirect methods increase uncertainty of gaged streamflow, model calibration at higher streamflow is potentially subject to greater error.

Structure designs and sites used for these simulations are for simulation purposes only and do not necessarily represent feasible structures or sites. There are several limitations related to structure scenarios. First, structures were "designed" only to the extent needed to develop hydraulic characteristics for the structure in the HSPF model. Mathematical storagedischarge relations were developed for each structure. These relations depend largely on dam heights, spillway characteristics (elevation, width, pipe/culvert diameter, and so forth), and topographical characteristics at each site. Specifications for actual structures in an adjacent watershed, designed for similar purposes (San Antonio River Authority, 1996), were used as a guide for dam and spillway heights. Actual physical characteristics such as dam type and construction materials were not considered in the structure design. Geotechnical analyses to determine suitability of any particular site were not done. Furthermore, safety factors, such as flood-frequency analyses to determine possible extreme flows that the structures could be exposed to, were not considered. Finally, cost of land and other factors related to possible future acquisition or rights to construct structures at specific sites were not considered.

\section{Summary}

The U.S. Geological Survey (USGS), in cooperation with the U.S. Army Corps of Engineers-Fort Worth District, San Antonio River Authority, San Antonio Water System, and Guadalupe-Blanco River Authority, developed, calibrated, and tested a Hydrological Simulation Program-FORTRAN (HSPF) watershed model to simulate streamflow and estimate recharge in the 274-square-mile upper Cibolo Creek watershed in Bandera, Bexar, Comal, and Kendall Counties in 
south-central Texas. Input data for use with the HSPF model were developed from available rainfall, evapotranspiration, and streamflow data collected during 1992-2004. The error in simulated streamflow volume (difference between simulated and gaged streamflow) at the outlet of the study-area watershed (USGS streamflow-gaging station 08185000 Cibolo Creek at Selma) for 1997-2004 was about 2 percent.

Simulated streamflows at five selected sites were compared. Streamflow per unit area of contributing watershed, or runoff expressed in inches per year, decreased in the downstream direction, primarily because of substantial streamflow losses to ground-water recharge in Cibolo Creek. More than one-half (56 percent) of streamflow during 1992-2004 infiltrated to ground water in stream channels before it reached the USGS gaging station at Selma.

Simulations showed that during 1992-2004 average ground-water recharge in the watershed was 79,800 acrefeet per year, or 5.47 inches per year. Most recharge (about 74 percent) occurred as stream channel-infiltration. Diffuse recharge accounted for about 26 percent of total recharge. Most recharge (about 77 percent) occurred in the Trinity aquifer outcrop. About 13 percent of recharge occurred in the area of transition from the Trinity aquifer outcrop to the Edwards aquifer outcrop. About 6.4 percent of recharge occurred in the Edwards aquifer recharge zone (outcrop), and a small amount (about 3.6 percent) of recharge occurred in the area of transition from the Edwards aquifer recharge zone (outcrop) to the Edwards aquifer upper confining unit, and in the upper confining unit.

Streamflow and recharge in the study area are greatly influenced by large storms. During the 1992-2004 period, three large storms (June 1997, October 1998, and July 2002) accounted for about 11 percent of the study-area rainfall, 61 percent of streamflow (measured at the Selma station), and 16 percent of the total ground-water recharge. Annual streamflow and recharge are highly variable. During 1999, a dry year with about 16 inches of rainfall and no measured runoff at the watershed outlet, recharge in the watershed amounted to only 14,500 acre-feet (0.99 inch) compared with 196,000 acre-feet (13.43 inches) during 1992, a relatively wet year with about 54 inches of rainfall.

The calibrated Cibolo Creek HSPF model was used to simulate streamflow and recharge for various scenarios involving flood-control/recharge-enhancement structures located at different sites in the watershed. The purpose of the simulations was to determine whether such structures could potentially provide flood control and increase recharge benefits in the upper Cibolo Creek watershed. Simulations showed that larger structures on Cibolo Creek, compared with smaller structures on tributaries, resulted in larger flood-peak reduction and larger increases in recharge. One scenario that included two structures on the main stem of Cibolo Creek resulted in a 37 -percent reduction in peak flow at the watershed outlet and an increase in recharge in stream channels. With this scenario, stream-channel recharge increased 6.6 percent in the Trin- ity aquifer outcrop and 12.6 percent in the Edwards aquifer outcrop.

\section{References}

Atmospheric Radiation Measurement Program, 2003, Energy balance Bowen ratio: accessed November 8, 2003, at http://www.arm.gov/docs/instruments/static/ebbr.html

Benson, M.A., and Dalrymple, Tate, 1967, General field and office procedures for indirect discharge measurements: U.S. Geological Survey Techniques of Water Resources Investigations, book 3, chap. A1, $30 \mathrm{p}$.

Bicknell, B.R., Imhoff, J.C., Kittle, J.L. Jr., Donigian, A.S., and Johanson, R.C., 1997, Hydrological Simulation Program-FORTRAN, user's manual for version 11: Research Triangle Park, N.C., U.S. Environmental Protection Agency, National Exposure Research Laboratory, Office of Research and Development, $755 \mathrm{p}$.

Bomar, G.W., 1994, Texas weather (2d ed., revised): Austin, University of Texas Press, 287 p.

Brown, D.S., and Raines, T.H., 2002, Simulation of flow and effects of best-management practices in the upper Seco Creek Basin, south-central Texas, 1991-98: U.S. Geological Survey Water-Resources Investigations Report 02-4249, $22 \mathrm{p}$.

City of Boerne, 2003, City of Boerne profile-demographics: accessed November 14, 2003, at http://www.ci.boerne. tx.us/profile.html

Clark, A.K., 2003, Geologic framework and hydrologic features of the Glen Rose Limestone, Camp Bullis Training Site, Bexar County, Texas: U.S. Geological Survey WaterResources Investigations Report 03-4081, 9 p.

Donigian, A.S., Jr., 2002, Watershed model calibration and validation-The HSPF experience, in National TMDL Science and Policy 2002, Phoenix, Arizona, November 13-16, 2002, Specialty Conference Proceedings: Water Environment Federation, 30 p., accessed November 24, 2006, at http://www.aquaterra.com/TMDL.Nov02.Donigian. Paper.doc

Donigian, A.S., Jr., Bicknell, B.R., and Imhoff, J.C., 1995, Hydrological Simulation Program-FORTRAN (HSPF), in Singh, V.P., ed., Computer models of watershed hydrology: Highlands Ranch, Colo., Water Resources Publications, p. 395-442.

Donigian, A.S., Jr., Imhoff, J.C., Bicknell, B.R., and Kittle, J.L., Jr., 1984, Application guide for Hydrological Simulation Program-FORTRAN (HSPF): U.S. Environmental Protection Agency, Environmental Research Laboratory, EPA-600/3-84-065, 177 p. 
Gandara, S.C., 2003, Water resources data, Texas, water year 2002-Volume 5. Guadalupe River Basin, Nueces River Basin, Rio Grande Basin, and intervening coastal basins: U.S. Geological Survey Water-Data Report TX-02-5, $382 \mathrm{p}$.

George, W.O., 1952, Geology and ground-water resources of Comal County, Texas: U.S. Geological Survey WaterSupply Paper 1138, 126 p.

Larkin, T.J., and Bomar, G.W., 1983, Climatic atlas of Texas: Texas Department of Water Resources, Limited Printing Report LP-192, 151 p.

Lumb, A.M., McCammon, R.B., and Kittle, J.L., Jr., 1994, Users manual for an expert system (HSPEXP) for calibration of the Hydrological Simulation Program-FORTRAN: U.S. Geological Survey Water-Resources Investigations Report 94-4168, 102 p.

Maclay, R.W., 1995, Geology and hydrology of the Edwards aquifer in the San Antonio area, Texas: U.S. Geological Survey Water-Resources Investigations Report 95-4186, $64 \mathrm{p}$.

National Climatic Data Center, 2006, Weather/climate events, information \& assessments-Weather/climate data and products: accessed October 10, 2006, at http://www.ncdc.noaa.gov/oa/ncdc.html

Ockerman, D.J., 2002, Simulation of runoff and recharge and estimation of constituent loads in runoff, Edwards aquifer recharge zone (outcrop) and catchment area, Bexar County, Texas, 1997-2000: U.S. Geological Survey WaterResources Investigations Report 02-4241, 31 p.

Owens, M.K., Lyons, Robert, and Kneuper, Charles, 2001, Evaporation and interception water loss from juniper communities on the Edwards aquifer recharge area: Uvalde, Tex., Texas Agricultural Experiment Station and Texas Agricultural Extension Service, Final Report, accessed July 23, 2007, at http://uvalde.tamu.edu/intercept/final.pdf

Price, D.L., Passmore, M.F., and McLendon, Terry, 2001, EDYS_Ecological dynamics simulation: U.S. Army Corps of Engineers, Research and Development Center, Ecosystem Evaluation and Engineering Division, Montgomery Watson Harza Ecological Systems Division, fact sheet, 1 p.

Puente, Celso, 1978, Method of estimating natural recharge to the Edwards aquifer in the San Antonio area, Texas: U.S. Geological Survey Water-Resources Investigations Report 78-10, 34 p.

San Antonio River Authority, 1996, Salado Creek watershed protection and flood prevention project: San Antonio, San Antonio River Authority, fact sheet, 2 p.

San Antonio Water System, 2006, Edwards aquifer recharge initiative: accessed December 12, 2006, at http://www.saws. org/our_water/waterresources/projects/edwards_recharge. shtml
Small, T.A., and Hanson, J.A., 1994, Geologic framework and hydrologic characteristics of the Edwards aquifer outcrop, Comal County, Texas: U.S. Geological Survey WaterResources Investigations Report 94-4117, 10 p.

Stein, W.G., and Ozuna, G.B., 1996, Geologic framework and hydrologic characteristics of the Edwards aquifer recharge zone, Bexar County, Texas: U.S. Geological Survey WaterResources Investigations Report 95-4030, 8 p.

Texas Board of Water Engineers, 1960, Channel gain and loss investigations, Texas streams, 1918-1958: Texas Board of Water Engineers Bulletin 5807D, 270 p.

U.S. Army Corps of Engineers, 2001, Project management plan, Guadalupe-San Antonio River Basins, Cibolo Creek watershed feasibility study: U.S. Army Corps of Engineers, Fort Worth District.

U.S. Census Bureau, 2003, State and county quickfacts: accessed May 8, 2007, at http://quickfacts.census.gov/qfd/ states/48000.html

U.S. Department of Agriculture, Soil Conservation Service [Natural Resources Conservation Service], 1966, Soil survey of Bexar County, Texas: Soil Conservation Service, 126 p., 88 map sheets.

U.S. Department of Agriculture, Soil Conservation Service [Natural Resources Conservation Service], 1981, Soil survey of Kendall County, Texas: Soil Conservation Service, 87 p., 22 map sheets.

U.S. Department of Agriculture, Soil Conservation Service [Natural Resources Conservation Service], 1984, Soil survey of Comal and Hays Counties, Texas: Soil Conservation Service, 136 p., 106 map sheets.

U.S. Environmental Protection Agency, 2003, BASINS (Better Assessment Science Integrating Point and Nonpoint sources): accessed April 28, 2007, at http://www.epa.gov/ waterscience /basins/.

U.S. Geological Survey, 2003, Elevation program: U.S. Geological Survey, Rocky Mountain Mapping Center, accessed December 5, 2006, at http://rockyweb.cr.usgs.gov/elevation/.

U.S. Geological Survey, 2006, National Water Information System (NWISWeb) data available on the World Wide Web, accessed October 6, 2006, at http://waterdata.usgs.gov/tx/ nwis/nwis

University of Texas, Bureau of Economic Geology, 1995, The Guadalupe-Lavaca-San Antonio-Nueces River Basins regional study_-Biologic assemblages, San Antonio EastLlano East sheets: Austin, pl. 4.

Wicklein, S.M., and Schiffer, D.M., 2002, Simulation of runoff and water quality for 1990 and 2008 land-use conditions in the Reedy Creek watershed, east-central Florida: U.S. Geological Survey Water-Resources Investigations Report 02-4018, 62 p. 
Table 5. Streamflow calibration and testing results, Hydrological Simulation Program—FORTRAN model, upper Cibolo Creek watershed, south-central Texas, 1992-2004.

[acre-ft, acre-feet; $\mathrm{ft}^{3} / \mathrm{s}$, cubic feet per second; --, not applicable]

Cibolo Creek at Interstate Highway 10 above Boerne, Texas (08183850)

\begin{tabular}{|c|c|c|c|c|}
\hline Comparison of streamflow volumes and peaks & $\begin{array}{l}\text { Measured } \\
\text { streamflow }\end{array}$ & $\begin{array}{l}\text { Simulated } \\
\text { streamflow }\end{array}$ & $\begin{array}{c}\text { Error }^{1} \\
\text { (percent) }\end{array}$ & $\begin{array}{c}\text { Criteria }^{2} \\
\text { (percent) }\end{array}$ \\
\hline \multicolumn{5}{|l|}{ Calibration period $1997-2000$} \\
\hline Total flow volume, acre-ft & 50,400 & 49,800 & -1.2 & 10.0 \\
\hline Total of highest 10 percent of daily flows, acre-ft & 36,000 & 34,600 & -3.9 & 15.0 \\
\hline Total of lowest 50 percent of daily flows, acre-ft & 1,600 & 1,750 & 9.4 & 10.0 \\
\hline Average of selected storm peaks, $\mathrm{ft}^{3} / \mathrm{s}$ (three storms) & 7,590 & 8,950 & 17.9 & -- \\
\hline \multicolumn{5}{|l|}{ Testing period 2001-04 } \\
\hline Total flow volume, acre-ft & 91,600 & 87,500 & -4.5 & 10.0 \\
\hline Total of highest 10 percent of daily flows, acre-ft & 59,500 & 62,800 & 5.5 & 15.0 \\
\hline Total of lowest 50 percent of daily flows, acre-ft & 6,040 & 5,130 & -15.1 & 10.0 \\
\hline Average of selected storm peaks, $\mathrm{ft}^{3} / \mathrm{s}$ (three storms) & 5,610 & 3,260 & -41.9 & -- \\
\hline \multicolumn{5}{|l|}{ Entire (calibration and testing) period 1997-2004 } \\
\hline Total flow volume, acre-ft & 142,000 & 137,000 & -3.5 & 10.0 \\
\hline Total of highest 10 percent of daily flows, acre-ft & 98,400 & 97,700 & -.7 & 15.0 \\
\hline Total of lowest 50 percent of daily flows, acre-ft & 5,680 & 4,920 & -13.4 & 10.0 \\
\hline Average of selected storm peaks, $\mathrm{ft}^{3} / \mathrm{s}$ (six storms) & 6,600 & 6,100 & -7.6 & -- \\
\hline Model-fit statistics 1997-2004 & Annual & Monthly & Daily & Hourly \\
\hline Number of years, months, days, or hours & 8 & 96 & 2,922 & 70,128 \\
\hline Coefficient of determination & .94 & .98 & .95 & .87 \\
\hline Coefficient of model-fit efficiency & .91 & .96 & .91 & .82 \\
\hline Percent time simulated within 10 percent of measured & 37.5 & 22.9 & 22.6 & 22.1 \\
\hline Percent time simulated within 25 percent of measured & 41.7 & 34.4 & 36.2 & 36.1 \\
\hline
\end{tabular}

Cibolo Creek near Boerne, Texas (08183900)

\begin{tabular}{lcccc}
\hline \multicolumn{1}{c}{ Comparison of streamflow volumes and peaks } & $\begin{array}{c}\text { Measured } \\
\text { streamflow }\end{array}$ & $\begin{array}{c}\text { Simulated } \\
\text { streamflow }\end{array}$ & $\begin{array}{c}\text { Error }^{1} \\
\text { (percent) }\end{array}$ & $\begin{array}{c}\text { Criteria }^{2} \\
\text { (percent) }\end{array}$ \\
\hline \multicolumn{1}{c}{ Testing period 1992-94 } & & & & \\
Total flow volume, acre-ft & 96,600 & 96,600 & -4.8 & 10.0 \\
Total of highest 10 percent of daily flows, acre-ft & 58,300 & 54,900 & -5.8 & 15.0 \\
Total of lowest 50 percent of daily flows, acre-ft & 5,510 & 5,310 & -3.6 & 10.0 \\
Average of selected storm peaks, ft's (three storms) & 6,980 & 7,420 & 6.3 & -- \\
\hline \multicolumn{1}{c}{ Model-fit statistics 1992-94 } & & & & \\
\hline & Annual & Monthly & Daily & Hourly \\
\hline Number of years, months, days, or hours & 3 & 36 & 1,096 & 26,280 \\
Coefficient of determination & 1.00 & .96 & .93 & .82 \\
Coefficient of model-fit efficiency & .99 & .94 & .92 & .77 \\
Percent time simulated within 10 percent of measured & 66.7 & 25.0 & 15.0 & 29.8 \\
Percent time simulated within 25 percent of measured & 100 & 55.6 & 38.7 & 39.0 \\
\hline
\end{tabular}




\section{Simulation of Streamflow and Estimation of Ground-Water Recharge in the Upper Cibolo Creek Watershed}

Table 5. Streamflow calibration and testing results, Hydrological Simulation Program—FORTRAN model, upper Cibolo Creek watershed, south-central Texas, 1992-2004-Continued.

Cibolo Creek at Selma, Texas (08185000)

\begin{tabular}{|c|c|c|c|c|}
\hline Comparison of streamflow volumes and peaks & $\begin{array}{l}\text { Measured } \\
\text { streamflow }\end{array}$ & $\begin{array}{l}\text { Simulated } \\
\text { streamflow }\end{array}$ & $\begin{array}{c}\text { Error }^{1} \\
\text { (percent) }\end{array}$ & $\begin{array}{l}\text { Criteria }^{2} \\
\text { (percent) }\end{array}$ \\
\hline \multicolumn{5}{|l|}{ Calibration period 1997-2000 } \\
\hline Total flow volume, acre-ft & 230,000 & 226,000 & -1.7 & 10.0 \\
\hline Total of highest 10 percent of daily flows, acre- $\mathrm{ft}$ & 230,000 & 226,000 & -1.7 & 15.0 \\
\hline Total of lowest 50 percent of daily flows, acre-ft & 0 & 0 & 0 & 10.0 \\
\hline Average of selected storm peaks, $\mathrm{ft}^{\mathrm{t}} / \mathrm{s}$ (three storms) & 56,700 & 48,300 & -14.8 & -- \\
\hline \multicolumn{5}{|l|}{ Testing period 2001-04 } \\
\hline Total flow volume, acre-ft & 248,000 & 262,000 & 5.6 & 10.0 \\
\hline Total of highest 10 percent of daily flows, acre- $\mathrm{ft}$ & 248,000 & 262,000 & 5.6 & 15.0 \\
\hline Total of lowest 50 percent of daily flows, acre-ft & 0 & 0 & 0 & 10.0 \\
\hline Average of selected storm peaks, $\mathrm{ft}^{\mathrm{t}} / \mathrm{s}$ (three storms) & 26,800 & 17,800 & -33.6 & -- \\
\hline \multicolumn{5}{|l|}{ Entire (calibration and testing) period 1997-2004 } \\
\hline Total flow volume, acre-ft & 478,000 & 488,000 & 2.1 & 10.0 \\
\hline Total of highest 10 percent of daily flows, acre-ft & 478,000 & 488,000 & 2.1 & 15.0 \\
\hline Total of lowest 50 percent of daily flows, acre-ft & 0 & 0 & 0 & 10.0 \\
\hline Average of selected storm peaks, $\mathrm{ft}^{3} / \mathrm{s}$ (six storms) & 41,700 & 33,000 & -20.9 & -- \\
\hline Model-fit statistics 1997-2004 & Annual & Monthly & Daily & Hourly \\
\hline Number of years, months, days, or hours & 8 & 96 & 2,922 & 70,128 \\
\hline Coefficient of determination & 1.00 & 1.00 & .97 & .91 \\
\hline Coefficient of model-fit efficiency & .99 & 1.00 & .97 & .90 \\
\hline Percent time simulated within 10 percent of measured & 75.0 & 79.2 & 91.7 & 92.6 \\
\hline Percent time simulated within 25 percent of measured & 75.0 & 80.2 & 92.5 & 93.3 \\
\hline
\end{tabular}

${ }^{1}$ Error $=[($ simulated-measured $) /$ measured $] \times 100$.

${ }^{2}$ Default error criteria from HSPEXP (Lumb and others, 1994). 
Table 6. Simulated evapotranspiration, upper Cibolo Creek watershed, and measured evapotranspiration, Honey Creek watershed, south-central Texas, March-December 2002.

[ET, evapotranspiration]

\begin{tabular}{lccc}
\hline Month & $\begin{array}{c}\text { Simulated ET (inches) } \\
\text { Cibolo Creek }\end{array}$ & $\begin{array}{c}\text { Measured ET (inches) } \\
\text { Honey Creek }\end{array}$ & $\begin{array}{c}\text { Error }^{2} \\
\text { (percent) }\end{array}$ \\
\hline March & 1.6 & 2.2 & -27 \\
April & 3.2 & 3.0 & 7 \\
May & 2.0 & 2.9 & -31 \\
June & 2.1 & 3.1 & -32 \\
July & 4.7 & 4.1 & 15 \\
August & 3.6 & 3.7 & -3 \\
September & 3.7 & 2.8 & 32 \\
October & 2.7 & 2.2 & 23 \\
November & 2.8 & 1.8 & 47 \\
December & 2.2 & 1.4 & 38 \\
March-December & 28.6 & 27.5 & 4 \\
\hline
\end{tabular}

${ }^{1}$ Simulated ET for PERLND type Glen Rose Limestone, juniper-live oak woodland, moderately dense.

${ }^{2}$ Error $=[($ simulated-measured $) /$ measured $] \times 100$. 


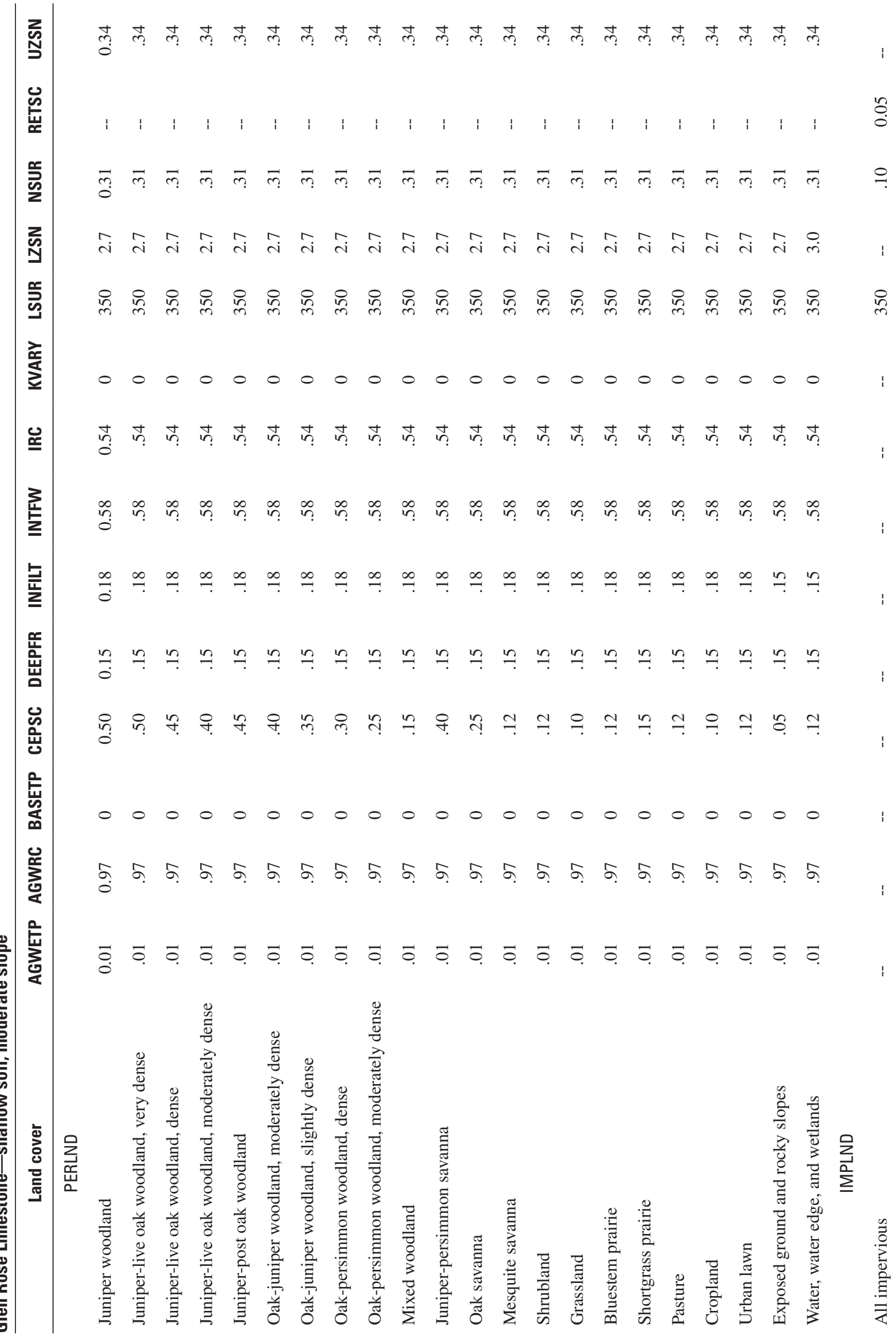




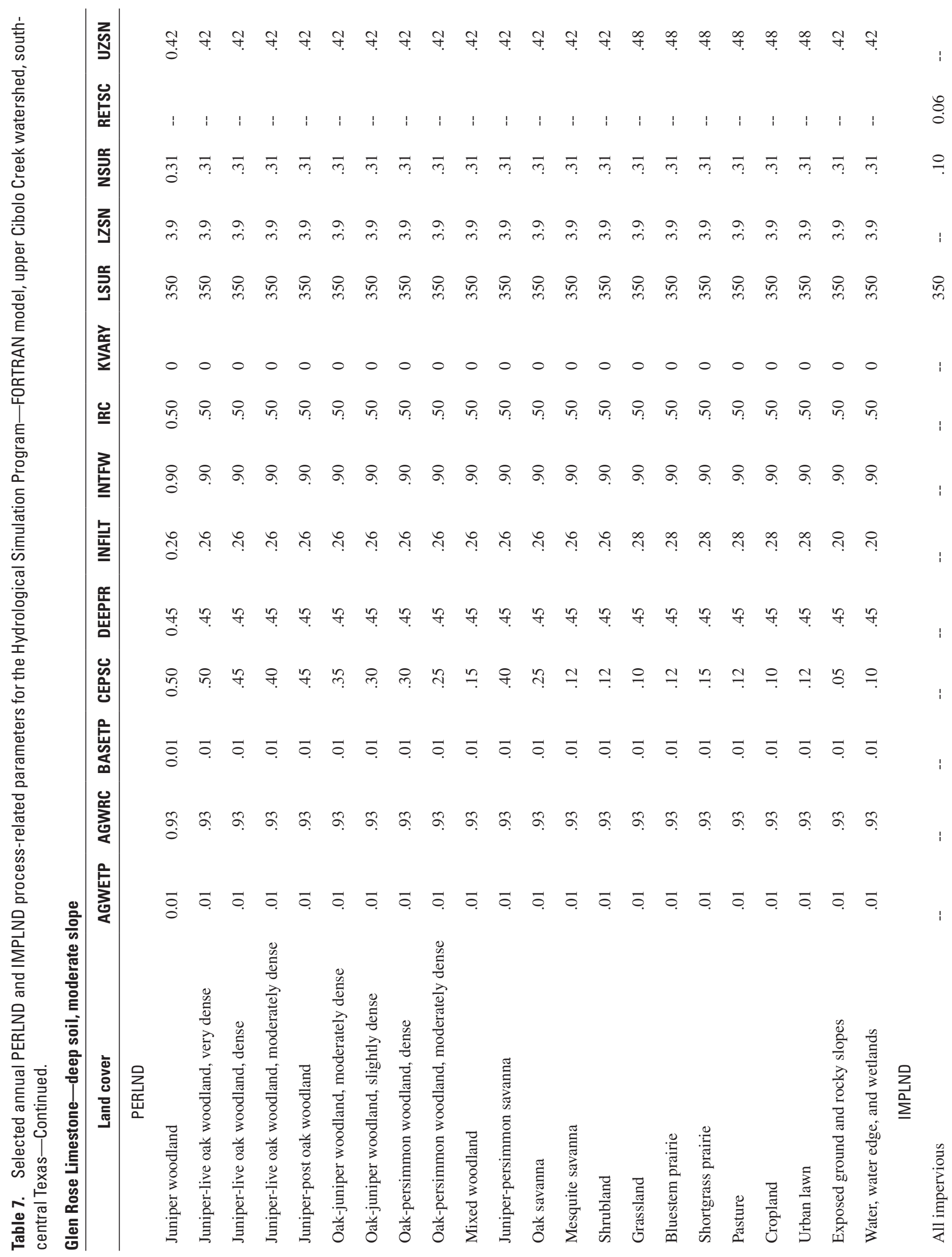




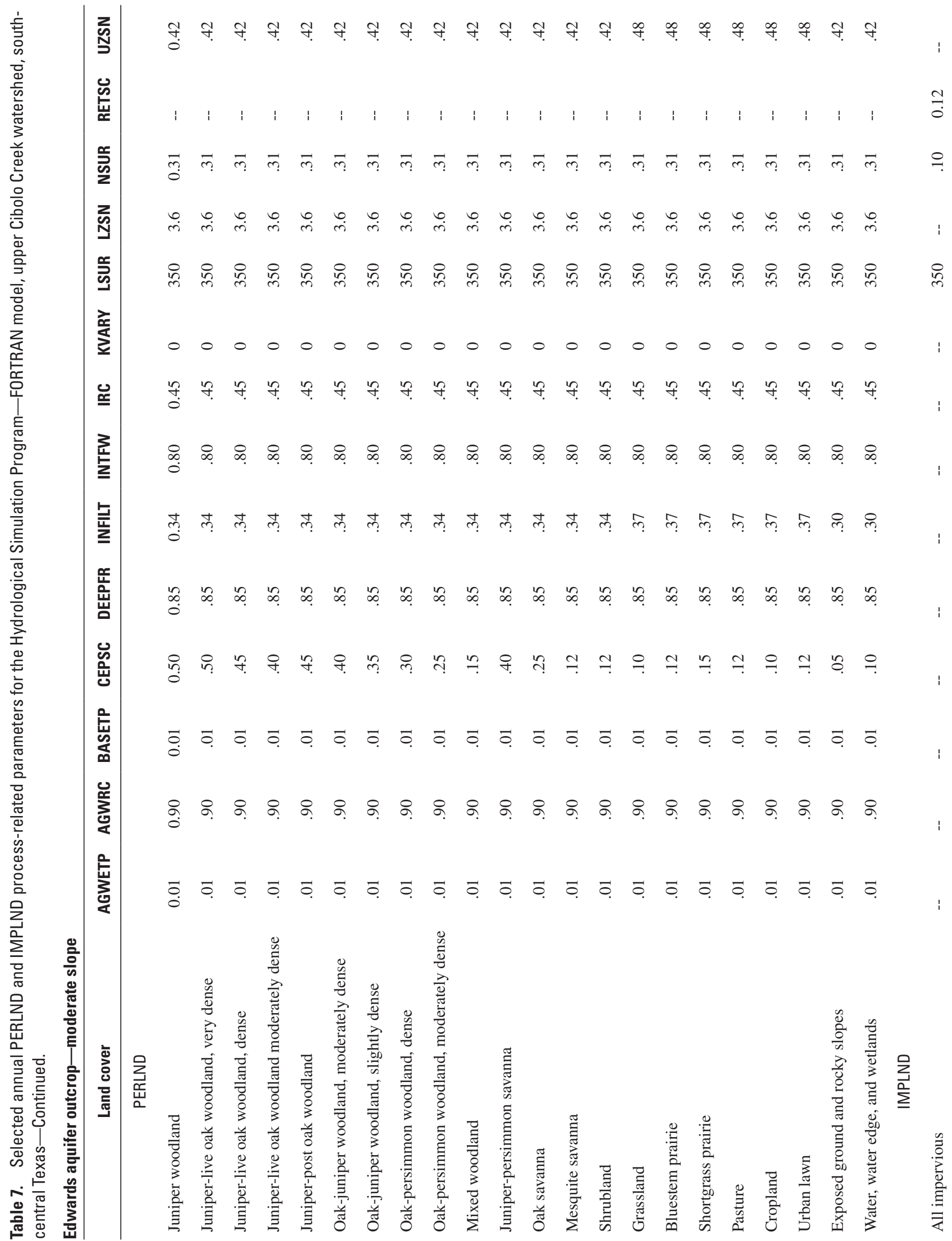




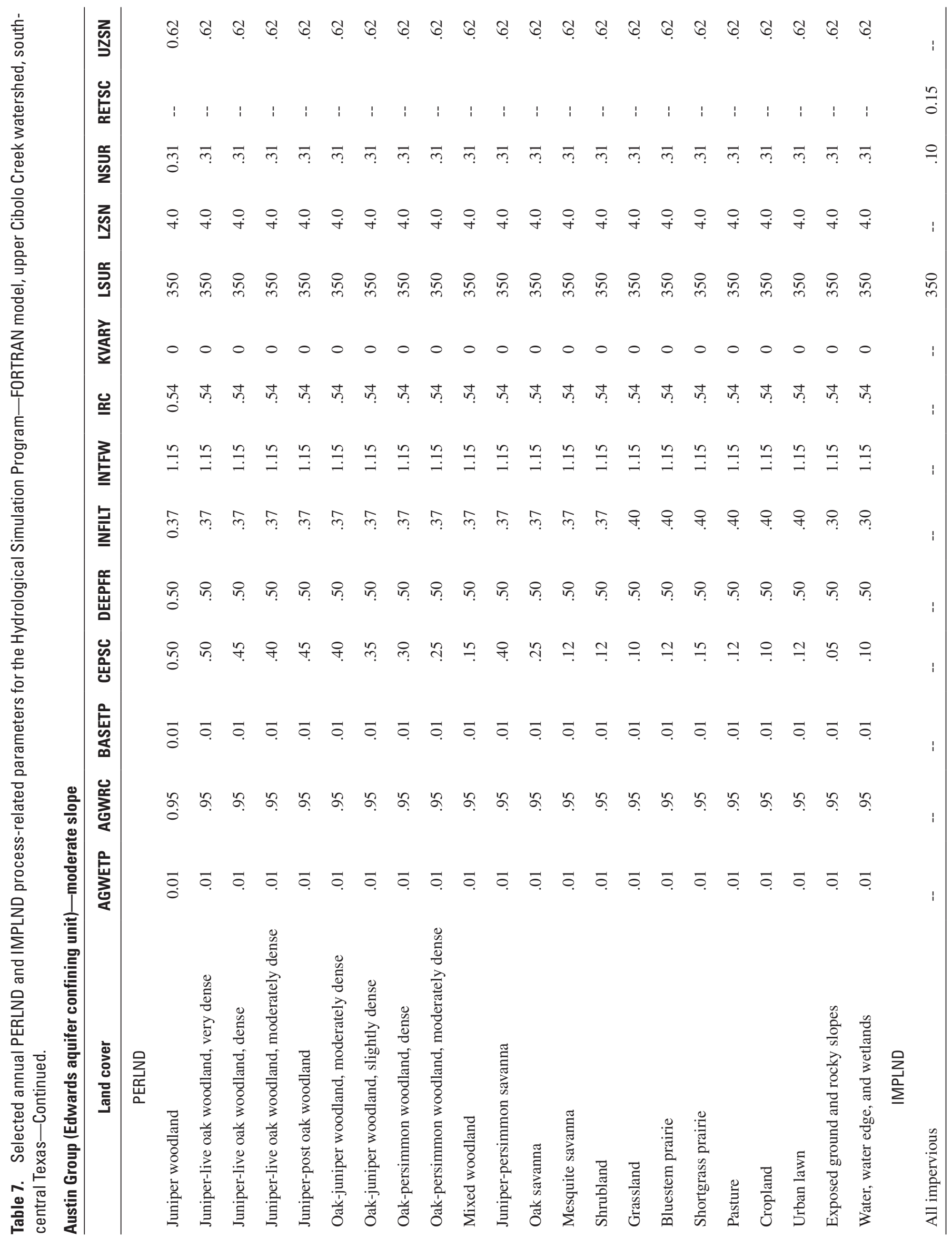




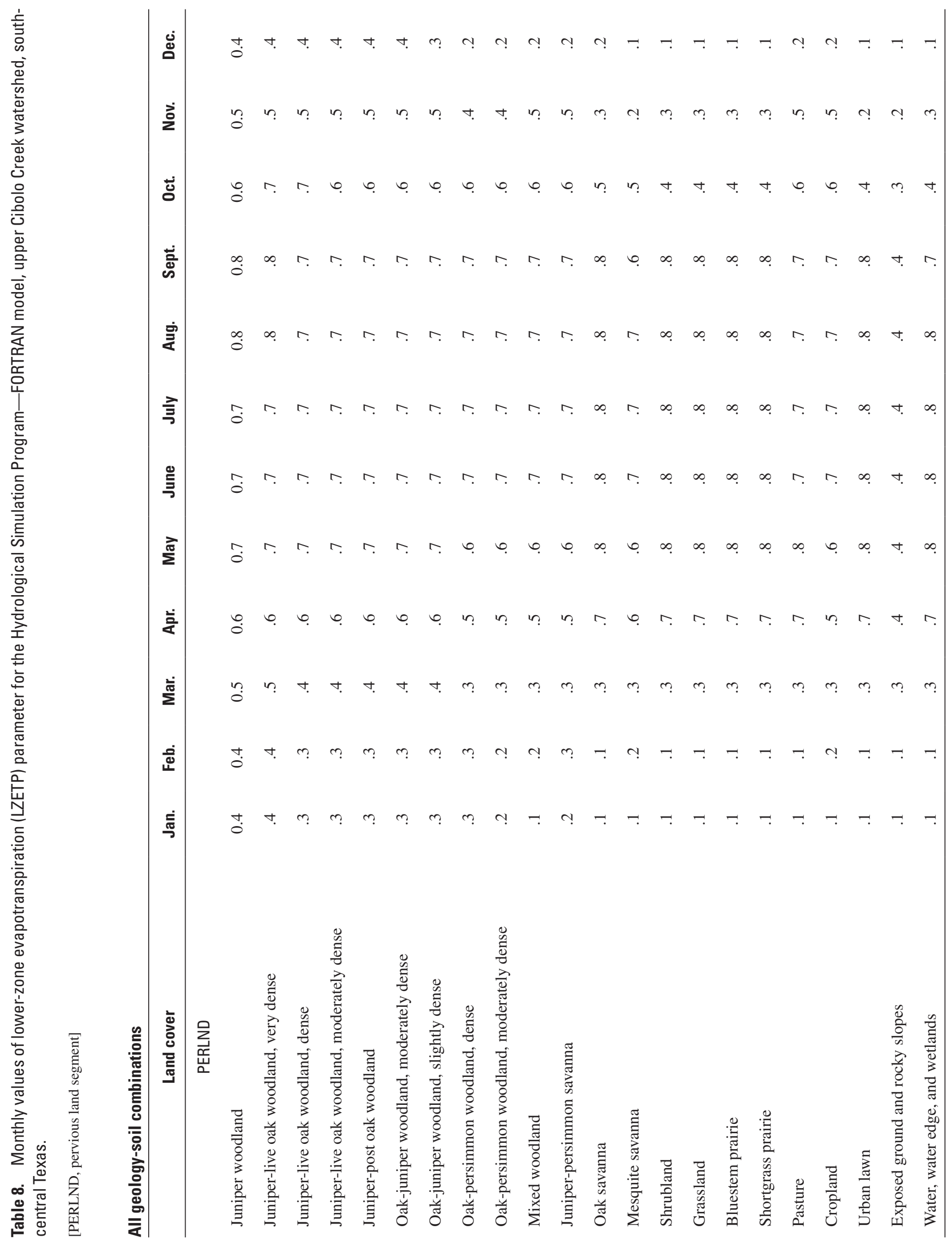


Table 9. Measured and simulated average annual streamflow per unit area (runoff) at selected sites on Cibolo Creek, south-central Texas, 1992-2004.

[Sites listed in downstream order; USGS, U.S. Geological Survey; RCHRES, stream or reservoir reach; --, not available]

\begin{tabular}{|c|c|c|c|c|}
\hline $\begin{array}{l}\text { Site } \\
\text { number } \\
\text { (fig. 5) }\end{array}$ & Location & $\begin{array}{l}\text { Drainage } \\
\text { area } \\
\text { (square } \\
\text { miles) }\end{array}$ & $\begin{array}{l}\text { Measured } \\
\text { runoff } \\
\text { (inches per year) }\end{array}$ & $\begin{array}{c}\text { Simulated } \\
\text { runoff } \\
\text { (inches per year) }\end{array}$ \\
\hline 10 & $\begin{array}{l}\text { USGS station } 08183850 \text { Cibolo Creek at Interstate Highway } \\
10 \text { above Boerne, Texas (downstream from confluence of } \\
\text { RCHRES } 26 \text { and RCHRES 28) }\end{array}$ & 29 & -- & 8.90 \\
\hline 12 & $\begin{array}{l}\text { USGS partial-record station } 08183950 \text { Cibolo Creek at Ralph } \\
\text { Fair Road below Boerne, Texas (outlet of RCHRES 88) }\end{array}$ & 112 & -- & 7.65 \\
\hline 15 & $\begin{array}{l}\text { USGS partial-record station } 08183995 \text { Cibolo Creek at U.S. } \\
\text { Highway } 281 \text { near Bulverde, Texas (outlet of RCHRES 154) }\end{array}$ & 179 & -- & 4.58 \\
\hline 17 & $\begin{array}{l}\text { USGS partial-record station } 08184300 \text { Cibolo Creek at Farm } \\
\text { Road } 1863 \text { below Bulverde, Texas (outlet of RCHRES 180) }\end{array}$ & 240 & -- & 3.76 \\
\hline 18 & $\begin{array}{l}\text { USGS station } 08185000 \text { Cibolo Creek at Selma, Texas (outlet of } \\
\text { RCHRES 212) }\end{array}$ & 274 & 3.16 & 3.22 \\
\hline
\end{tabular}

Table 10. Estimated annual rainfall and ground-water recharge, upper Cibolo Creek watershed, south-central Texas, 1992-2004.

\begin{tabular}{cccc}
\hline Year & $\begin{array}{r}\text { Rainfall } \\
\text { (inches) }\end{array}$ & $\begin{array}{c}\text { Recharge } \\
\text { (acre-feet) }\end{array}$ & $\begin{array}{c}\text { Recharge } \\
\text { (inches) }\end{array}$ \\
\hline 1992 & 54.24 & 196,000 & 13.43 \\
1993 & 28.02 & 45,600 & 3.13 \\
1994 & 36.01 & 49,500 & 3.39 \\
1995 & 28.68 & 33,200 & 2.28 \\
1996 & 24.19 & 15,600 & 1.07 \\
1997 & 48.70 & 94,000 & 6.44 \\
1998 & 48.88 & 119,000 & 8.16 \\
1999 & 15.83 & 14,500 & .99 \\
2000 & 34.38 & 66,900 & 4.58 \\
2001 & 44.49 & 125,000 & 8.57 \\
2002 & 49.45 & 124,500 & 8.53 \\
2003 & 26.92 & 48,000 & 3.29 \\
2004 & 46.69 & 105,000 & 7.20 \\
& & & 5.47 \\
\hline Average & 37.43 & 79,800 & \\
\hline
\end{tabular}




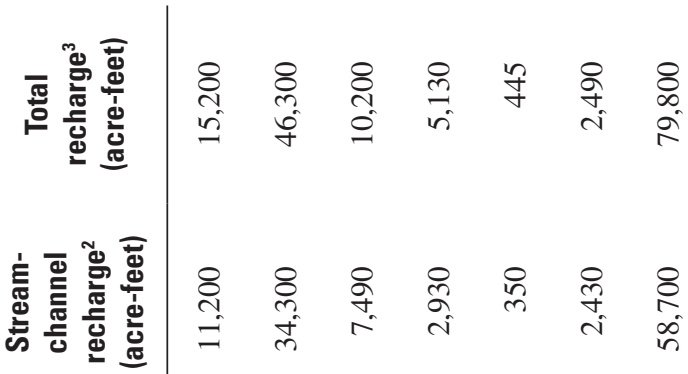

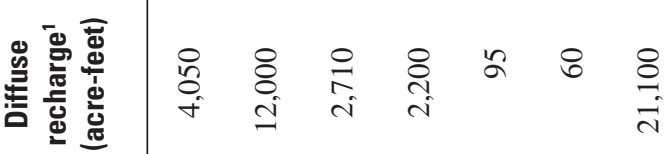

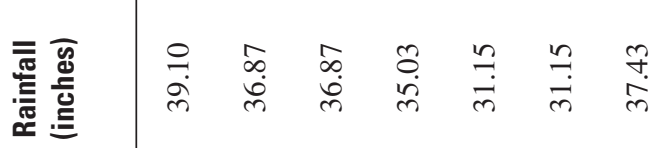

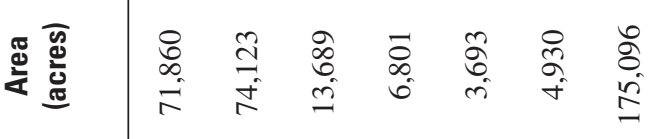

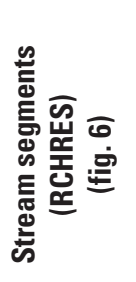

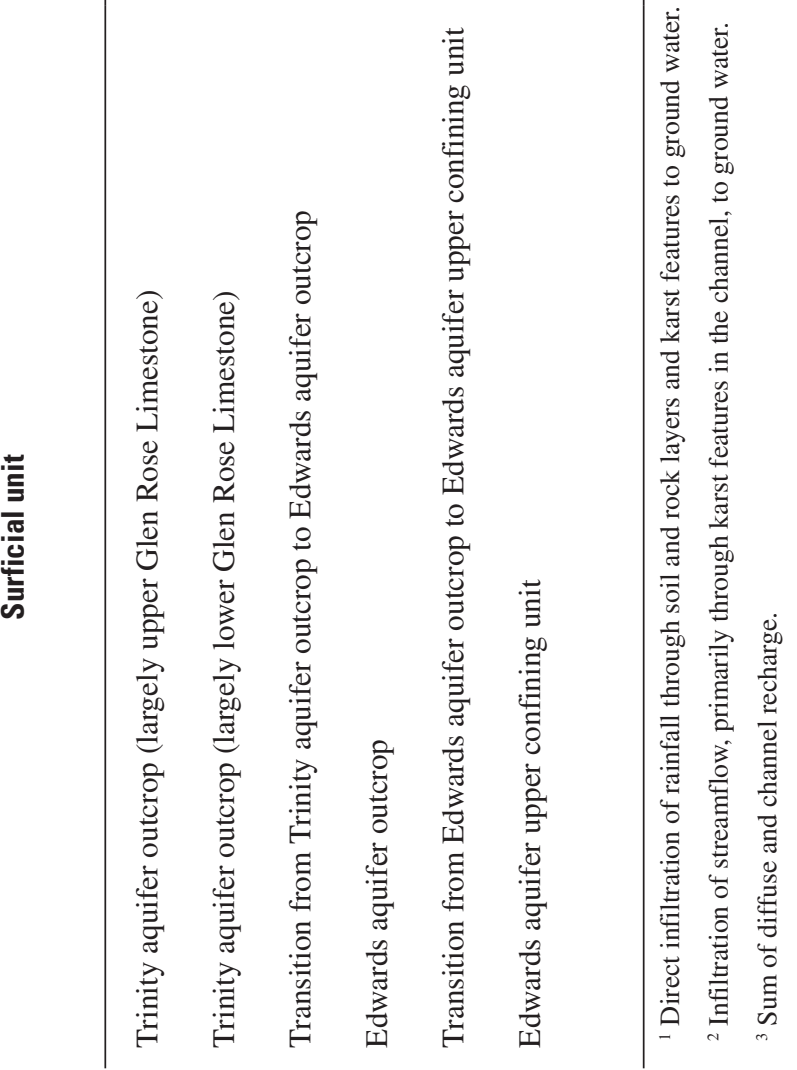




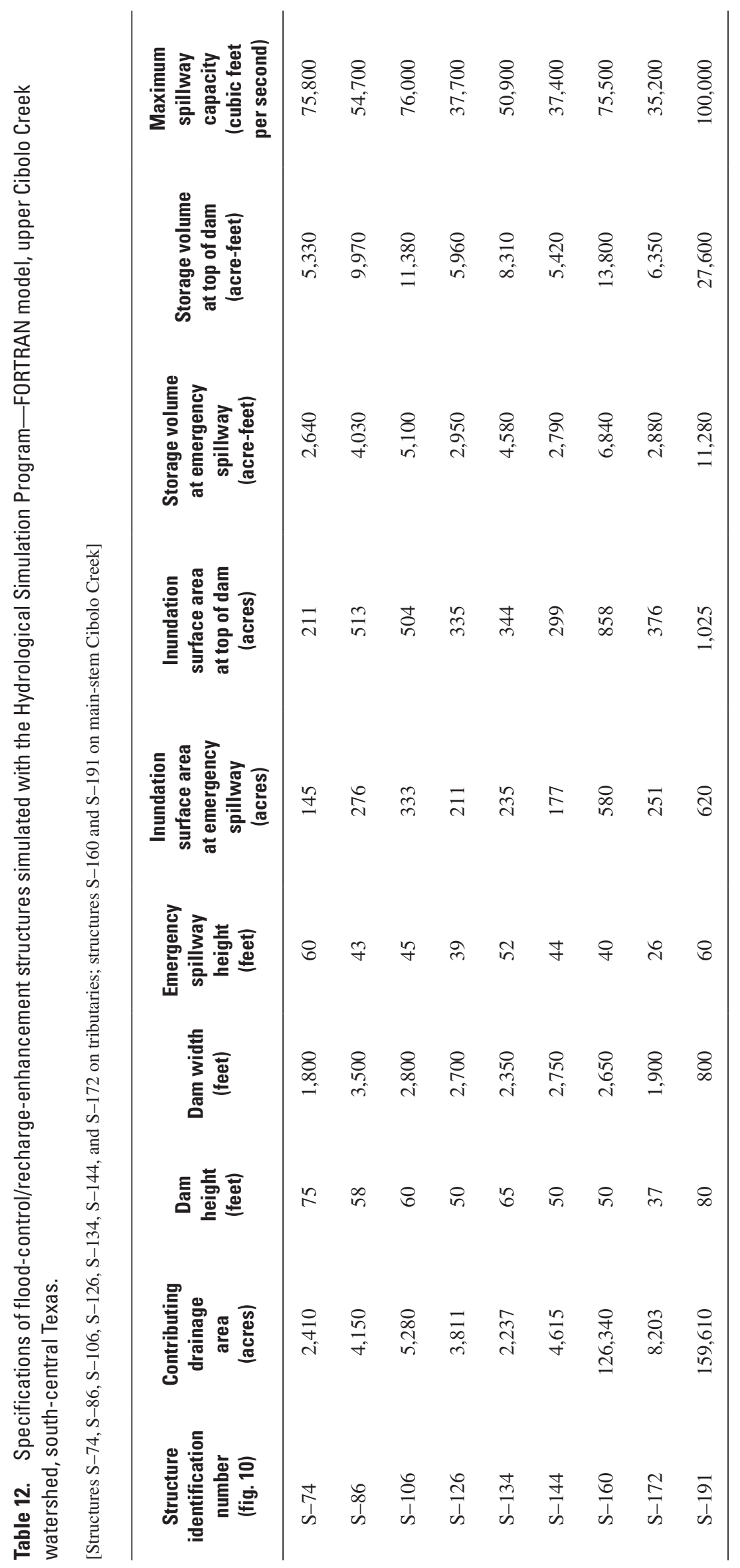




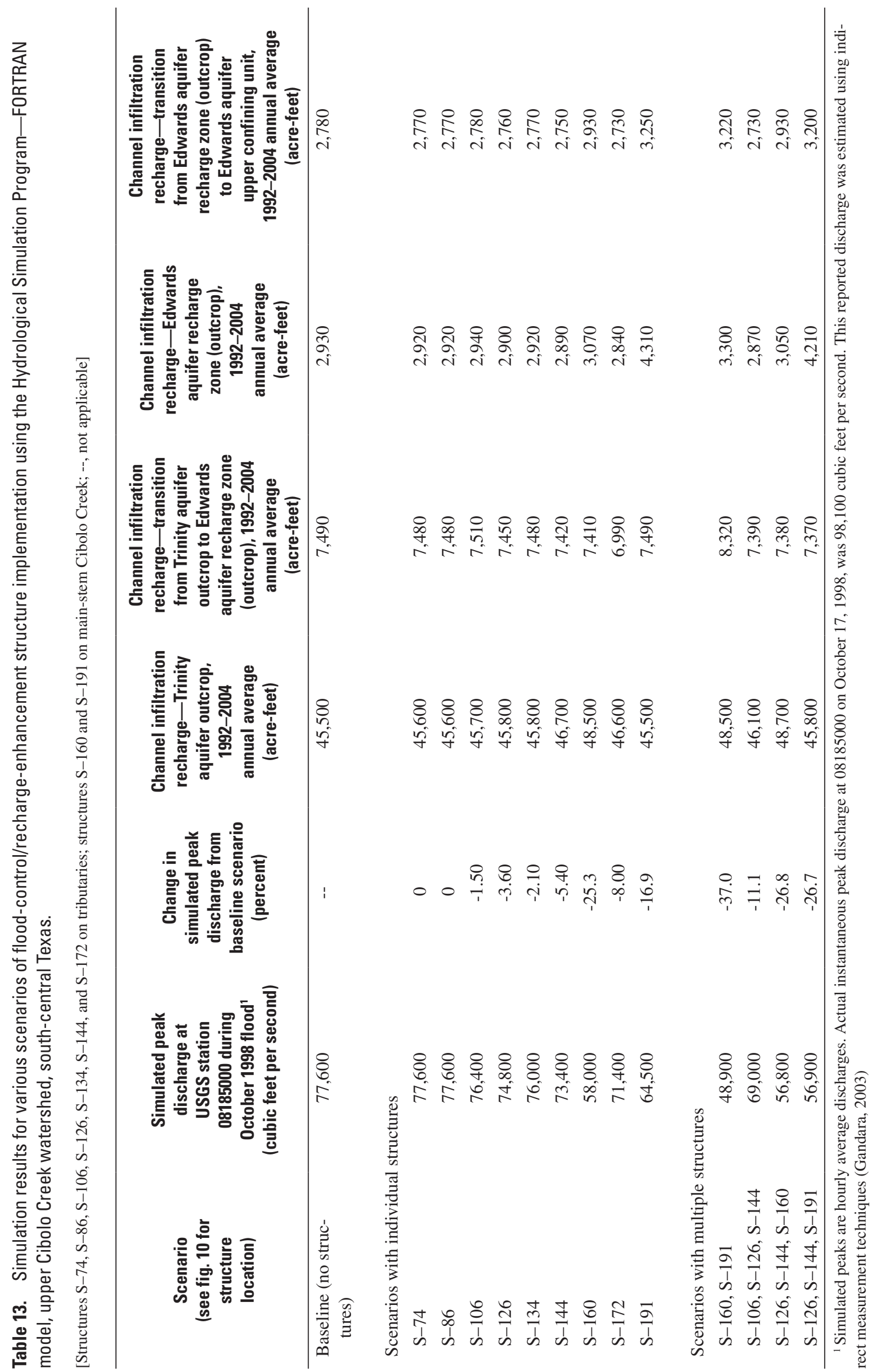


Prepared by the USGS Lafayette Publishing center.

Information regarding water resources in Texas is available at http: //tx.usgs.gov/ 